Summer 8-5-2021

\title{
Nurse Retention in Workplace Adversity
}

Deborah Lewis

University of St. Augustine for Health Sciences, d.lewis@usa.edu

DOI: https://doi.org/10.46409/sr.PUGT6955

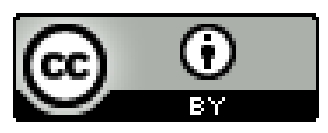

This work is licensed under a Creative Commons Attribution 4.0 License.

Follow this and additional works at: https://soar.usa.edu/scholprojects

Part of the Health and Medical Administration Commons, Leadership Studies Commons, and the Nursing Commons

\section{Recommended Citation}

Lewis, D. (2021). Nurse Retention in Workplace Adversity. [Doctoral project, University of St Augustine for Health Sciences]. SOAR @ USA: Student Scholarly Projects Collection. https://doi.org/10.46409/ sr.PUGT6955

This Scholarly Project is brought to you for free and open access by the Student Research at SOAR @ USA. It has been accepted for inclusion in Student Scholarly Projects by an authorized administrator of SOAR @ USA. For more information, please contact soar@usa.edu, erobinson@usa.edu. 


\title{
Nurse Retention in Workplace Adversity
}

\author{
Deborah Lynne Lewis MSN PHN RN \\ School of Nursing, University of St. Augustine for Health Sciences
}

This Manuscript Partially Fulfills the Requirements for

Doctor of Nursing Practice Program and is Approved by:

Theresa M. Pape PhD RN CNOR-E CNE

Rendi Solis DHA MSN RN NEA-BC CLSSGB FACHE

August 1, 2021 


\begin{abstract}
Practice Problem: Nurse turnover rate and lack of retention are issues that have an impact on safe patient care, patient mortality, quality outcomes, and patient experiences in the acute care units at the identified project setting. Turnover leads to excess labor utilization of overtime and increased hospital costs.
\end{abstract}

PICOT: The PICOT question that guided this project was $(\mathrm{P})$ In acute care hospital nurses, how do (I) nurse retention strategies $(\mathrm{C})$ compared with no nurse retention strategies $(\mathrm{O})$ reduce nurses' intention to leave and increase job satisfaction over (T) eight weeks?

Evidence: Twenty-one articles were reviewed that identified autonomy, recognition, acknowledgement, communication, and transformational leadership as nurse retention strategies, which contributed to a positive workplace environment and led to improved job satisfaction and nurse retention.

Intervention: The intervention consisted of focused communication that included staff recognition and acknowledgement by the nurse leaders of each unit, which had a positive effect on the workplace environment and job satisfaction.

Outcome: The results indicated a statistically insignificant change in job satisfaction and intent to stay yet did show a clinical significance.

Conclusion: The benefit of the project was that there was a clinically significant change in behaviors including: verbal expressions of increased job satisfaction, notable positive attitudes and hopefulness, as well as staff resilience. Consistent leadership and a larger sample size may produce statistical significance in a future study. 


\section{Nurse Retention in Workplace Adversity}

Nursing retention and high turnover rates, impact health care on many levels (Tang \& Hudson, 2019). There are substantial pressures on health care workers and facilities to provide quality care in a cost-effective manner to patients, in an effort to yield outcomes of satisfaction with both patients and staff (Bowles et al., 2019). Finding the balance with these pressures is a challenge. Nursing retention should be a priority across the globe, as many registered nurses $(\mathrm{RN})$ are often found leaving their positions when conditions and pressures becomes undesirable (Laschinger et al., 2016; WHO, 2010).

Turnover is expensive for health care facilities and often takes an emotional toll on nurses (Tang \& Hudson, 2019). Nursing turnover affects staff satisfaction, disrupts productivity, and impacts patient care. Patients are turned away due to inadequate staffing numbers, which in turn decreases revenue for the facility (Vardaman et al., 2018). In addition, nurses often feel disenfranchised and stressed, which has an impact on job satisfaction. Many nurses have left the profession because they felt that this challenge does not allow them to care appropriately for patients (Aiken et al., 2017; Spence Laschinger \& Fida, 2015). This paper discusses how positive workplace environment and job satisfaction have a significant role on nurse retention. The strategies implemented for increased retention of nursing staff were focused on improving the workplace environment and included direct communication, supportive management, and nurse autonomy with involvement in decision making. As the work environment improved through the implementation of interventions, a clinical significance was noted.

\section{Significance of the Practice Problem}

Surveys of nurses in different countries indicate turnover is a global issue and is a particular concern in rural and remote areas (Brook et al., 2019; Mbemba et al., 2013; WHO, 
2010). The extent and impact of nurse turnover has been noted in countries with developed healthcare systems. Furthermore, $20-50 \%$ of nurses surveyed in eight countries intended to leave their jobs, these countries included Belgium, France, Germany, Greece, Ireland, Poland, Spain, and Switzerland (Brook et al., 2019). Nursing turnover "has significant impact" on the provision of safe, quality care and patient mortality in those countries (Zander et al., 2016, p. 5).

In 2020, the vacancy rate of RNs climbed 9\% nationally; a full point higher than 2019 (NSI Nursing Solutions, 2021). The Bureau of Labor Statistics projected the nursing labor shortage will reach 1.13 million by 2024 (O’Donnell, 2020; Hogan \& Roberts, 2015). The rising rate of nursing shortages directly impacts patient quality outcomes and experiences. In addition, low nurse retention rates leads to excess labor utilization in both overtime and onboarding. Nationally, only one in five hospitals (19.3\%) reported an RN vacancy rate of $<5 \%$ in 2020, and in 2019 the national bedside RN turnover rate was 15.9\% (NSI Nursing Solutions, 2021). The average cost of one bedside nurse is $\$ 44,400$ annually, with an average hospital loss of $\$ 3.6 \mathrm{~m}$ $\$ 6.1 \mathrm{~m} /$ yearly (NSI Nursing Solutions, 2021).

The cost of turnover can have a profound impact on hospitals, and needs to be managed. Over $32 \%$ of newly hired RNs do not reach their first-year anniversary. For those nurses that surpassed the first-year anniversary, the turnover rate before reaching their second year of employment is $20.5 \%$ (O’Donnell, 2020). The northern California RN turnover rate in 2017 was $10.7 \%$, with a southern California turnover of rate $12.1 \%$ (Hospital Association of Southern California, 2017). It is estimated that hospitals lose between $\$ 4$ and $\$ 7$ million per year because of nurse turnover, and each percent change in $\mathrm{RN}$ turnover cost the average hospital an additional \$306,400 each year (NSI Nursing Solutions, 2021).

\section{PICOT Question}


The PICOT question guiding this project is: $(\mathrm{P})$ In acute care hospital nurses, how do (I) nurse retention strategies $(\mathrm{C})$ compared with no nurse retention strategies $(\mathrm{O})$ reduce nurses' intention to leave and increase job satisfaction over $(\mathrm{T})$ eight weeks?

Acute care nurses experience stressful situations routinely, related to high patient morbidity and mortality, as well as, encounter frequent traumatic and ethical issues that are often seen on acute care units (Mealer et al., 2016; McVicar, 2003; Strachota et al., 2003). High turnover rates and low retention of nurses on acute care units are significant problems in the United States health care system (Carter \& Tourangeau, 2012). The evidenced-based interventions for this project are nurse retention strategies of improving the work environment through the presence of supportive nurse managers, who were visible and available on the units; and the use of enhanced and focused communication techniques, to recognize and acknowledge nurses and their involvement in decision making. These were all shown to increase nurse retention and job satisfaction.

Nurse retention strategies were used for this project beginning in the first week of implementation. The expected outcomes were an increase of nurse retention intent and an increase in job satisfaction. The time frame was eight weeks with pre- and post-surveys for data collection of nurse participants, no risks were identified.

\section{Evidence-Based Practice Framework \& Change Theory}

The John Hopkins evidence-based practice framework had three sections: practice question, evidence, and translation. Once the PICOT question was formed the literature evidence was gathered, analyzed for translation into application, and then further reviewed. This evidence went into the project application once the personnel, health care workers, and institution were 
consulted about the project plan. Translation of the literature search provided the basis of the recommendations and action plan for this project.

The clinical practice issue was the need for increased retention among nursing staff in the acute care setting. The evidence from the literature review identified the importance of improvement of the workplace environment, using specific interventions to improve retention rates. The translation into practice included improved communication, provision of recognition and acknowledgment by the nurse manager, and daily nurse manager rounds to improve communication and relationships among staff (Gess, Manojlovich \& Warner, 2008). Support from stakeholders and resources were established in order to implement the project interventions. Once the 8-week project was completed and data collected, the outcomes were evaluated and reported to the stakeholders.

\section{Lewin's Change Theory}

Lewin's change theory consists of three stages: unfreezing, moving, and refreezing, which guided the practice change of the nurse retention strategies over eight weeks (Swanson \& Creed, 2014). The unfreezing stage increased the driving force to shift the nurses' behavior away from the status quo. This allowed for a decrease in the restraining forces that hindered project movement. The unfreezing stage also included the nurses who left the acute care unit, in order to investigate the reasons for the turnover. The project manager (DNP student) observed the units, shadowed nurses, spoke individually with nurses, held focus groups, and met with leadership on various occasions. The moving stage consisted of action by making changes through implementation and staff engagement. During this stage, the project manager (PM) identified nursing retention strategies through evidence-based research. The refreezing stage made the changes permanent using nursing strategies of improved communication between management 
and nursing staff, increased visibility of management, and a more engaged management style. These strategies, coupled with recognition and acknowledgment of the nursing staff accomplishments, created a positive workplace environment.

Lewin's change model acknowledged that leaders and change agents are often challenged to move forward. Change agents can assist in maintaining the advantages of both past practices and policies while also adapting to a rapidly changing environment (Swanson \& Creed, 2014). The project hospital had experienced multiple challenges such as changes in leadership, policies, availability of equipment, union consideration, nursing shortages, and staffing issues, which created a challenging work environment.

\section{Evidence Search Strategy}

Digital databases were searched electronically and included PubMed, ProQuest, and the Cumulative Index to Nursing and Allied Health Literature (CINAHL). The Boolean operators used for the searches were (nurse retention) AND (intent) and (nurse retention strategies) AND (intervention). The searches included academic journals, published within the last five years, in the English language.

\section{Evidence Search Results}

The initial search of CINAHL yielded 945 articles, Proquest 3,717 articles, and PubMed 913 articles, totaling 5,575 articles. Articles were screened and reviewed for inclusion criteria of (ICU) to (nurse retention) AND (intent) and (nurse retention strategies) AND (intervention), the remaining articles were from CINAHL 20, Proquest 448, and PubMed 15 totaling 483 articles. Once duplicates were merged and editorials, periodicals, and commentaries excluded, the outstanding articles for literature review totaled 21 (Figure 1). 
Synthesis of the literature identified autonomy, recognition, communication, organizational commitment, evidenced-based education/training, and transformational leadership as useful interventions to improve the workplace environment and job satisfaction. A summary of the primary articles (Appendix A) and systematic reviews (Appendix B) include the evidencebased nurse retention interventions.

The strength and quality of the evidence was evaluated by using the Johns Hopkins Nursing Evidenced Based Practice Synthesis Process and Recommendations (JHNEBP) Tool (Dang \& Dearholt, 2017). The resulting articles were a mix of level II evidence levels (n=9) with quasi-experimental and explanatory mixed method design studies, as well as, level I (n=9), level III ( $n=1)$ and level IV ( $n=1)$. Quality ratings were A or B indicating high quality and/or good quality representing strong, compelling and consistent evidence for the evidence search (Appendix H \& I).

\section{Themes with Practice Recommendations}

Themes that had an effect on nurse retention included: managers who created a positive workplace environment, using direct communication, staff recognition and acknowledgement, and nurses' inclusion in decision-making.

\section{Effective Leaders}

Effective leadership includes: staff empowerment, team-work, harmonious collaboration, inter-staff caring relationships, ethical practices, and support for fellow staff. Direct communication by acknowledging and recognizing nurses' work by management had an effect on job satisfaction and nurse retention (Nurdiana et al., 2018).

\section{Positive Workplace Environment}


A positive workplace environment requires open and direct communication, access to information, collaboration, and supportive nurse managers (Rivaz et al., 2020; Jackimowicz and Lewis, 2018; Dewanto and Warhani, 2018; Minamizono et al., 2019; Nurdiana et al., 2018; Van de Bulcke et al., 2020; Moisoglou et al., 2020; Lee et al., 2019; \& Whitehead et al., 2015).

\section{Communication, Acknowledgement, and Recognition}

Job satisfaction was influenced through open and direct communication, collaboration, and decision making (Jackimowicz et al., 2018; Van den Bulcke et al., 2020; Moisoglou et al., 2020; Coundounaris et al., 2020; \& Brown et al., 2018). The nurse managers who made a point to be active listeners with their health care staff, to share information, and use consistent follow up, improved communication on the unit, which may lead to increased nurse retention (Tang \& Hudson, 2019).

\section{Leadership Styles}

Leadership styles have a direct impact on a nurses' intent to stay, and indirectly affect the quality of health services provided to patients. Transformational leadership is a style that includes a defined nurse manager role, positive management support styles, supportive hospital management, and supportive organizational climates, to increase nurse retention (Labrague et al., 2020; Adams et al., 2019; Genly, 2016; Hussein et al., 2019; Jakimowicz et al., 2018; Moisoglou et al., 2020; Nurdiana et al., 2018; Putra et al., 2020; Ke \& Hung, 2017; Semachew et al., 2017; \& Brook et al., 2018). Positive, encouraging, visible and available managers have increased nurse retention on their units versus those managers not engaged with their staff (Labrague et al., 2020).

\section{Practice Recommendations}


Based on the literature and using the PICOT question, this DNP evidenced based project's recommended focus is on open and direct communication as the foundation of a positive workplace environment and an effective tool for successful management (Tang \& Hudson 2019; Nurdiana et al., 2019; Labrague et al., 2020; Adams et al., 2019). Effective communication also means that conflicts should be resolved in a supportive and proactive manner (Tang \& Hudson, 2019). The creation of a non-threatening, nurturing, and supportive workplace environment with open communication for expression of views and staff empowerment, may have a direct effect on job satisfaction and nurse retention for this project setting.

\section{Setting, Stakeholders, and Systems Change}

\section{Setting, Organizational Structure and Organizational Need}

The setting was a 400-bed acute care facility located in the southwestern part of the United States. It is one of the largest hospitals and the largest employer in the area. The leadership team consisted of the chief executive officer (CEO), the chief nursing officer (CNO), the chief operating officer (COO), the chief financial officer (CFO), the chief strategy officer (CSO), and the chief human resources officer (CHRO). Organizational need and support were determined by the $\mathrm{CNO}$, as well as, the acute care directors and nurse managers. Nurse retention has become a high priority to the organization, due to the increased turnover rate, which has the consequence of high costs to the organization and impacts the quality of care provided to patients. The volunteer participants in this pilot project were acute care nurses, totaling 20 participants, who were given surveys pre- and post- intervention implementation.

\section{Stakeholders and Organizational Support}


Due to the nursing turnover, there was a shortage of nursing staff, which was felt by other professionals in the organization, such as respiratory therapists, physical therapists, pharmacists, technicians, who were all supportive of this project. The stakeholders with active involvement were those from the leadership team, the PM, and the nursing staff for the selected units. Turnover is disruptive to nursing productivity, and with inadequate staffing this directly affects patients and their families, who are also important stakeholders in nurse retention efforts (Vardaman et al., 2018).

\section{Organizational Need and SWOT Analysis}

The SWOT analysis of the hospital identified the following strengths for this project, core experienced staff, adequate resources, and a busy unit with high census. Additionally, when the hospital offered a new graduate program, they had full capacity due to hospital outreach. The weaknesses noted for this project were the nursing shortage and high turnover rate. The opportunity is that the hospital is the largest employer in the area and is able to pilot this project. The threats were the negative media coverage, of nurses leaving the organization, and the nurses' negative perception of management. (Appendix G).

\section{Interprofessional Collaboration}

Interprofessional collaboration requires all stakeholders to take an active role in maintaining a positive workplace environment. The interprofessional staff have been impacted by the nursing turnover and low retention rates and have been doing their best to adjust to new, inexperienced nurses. However, the increase in the turnover rate not only affected patient care, but it also disrupted the collaboration among interprofessional staff.

\section{Project Overview}


Twenty volunteer nurse participants were randomly recruited from the acute care units. Inclusion was any nurse willing to participate, exclusion was any nurse who had submitted a resignation pre-survey intervention. The demographic data (Appendix F), the Job Satisfaction Survey (JSS) (Appendix D) and McCain's Intent to Stay (ITS) (Appendix E) were tools used for data collection and evaluation of both pre- and post-interventions via the Survey Monkey online tool. The comparison was made by using the data collected pre-intervention versus the data collected post-intervention.

\section{Project Objectives}

The project objectives proposed to increase nurse retention by improving the workplace environment, leading to increased job satisfaction and increased intent to stay:

1) Increased communication between nursing management and staff through focused, directed daily fifteen-minute rounds (see Table 2). Managers recorded themes from daily rounds for further follow-up and set a goal to interact individually with all staff 2-3 times monthly.

2) Nurse managers led focus groups directed by themes from daily rounds monthly.

3) Recognition and acknowledgment by management of nursing staff achievements during meetings and huddles.

4) Recognition by peers of a job well done in meetings and huddles.

5) Hospital internal communication acknowledged and recognized staff accomplishments to include birthdays and educational achievements. This recognition was based on the staff's personal preference of allocation. Data collection and measurement of the intervention was achieved through email surveys, to assess effectiveness of recognition of achievements in one week. 
6) A $30-60$ second inspirational quote during meetings was used in an effort to begin the day with a positive outlook and to set the tone of the shift. Staff were encouraged to participate with their own quotes.

\section{Schedule of Activities and Timeline}

The schedule and timeline of activities were as follows:

- Week 1- 2: meetings were held with nursing staff to inform them of the project on the units and recruitment of 20 volunteer nurse participants. Pre-intervention tools (Demographics, JSS, ITS surveys) were given to nurse participants via email with an online link to the surveys. Increased visibility of managers on the units through focus groups and 15-minute walking rounds, as well as, daily huddles, which included a 30-60 second inspirational quote.

- Week 3: hospital internal communications were initiated for staff recognition of achievements, such as birthdays and educational achievements to be acknowledged during meetings, emails and/or cards, depending on employee preference.

- Week 4-6: Nurse manager led themed focus groups were generated from the daily walking rounds.

- Week: 7-9: Observation were conducted by the PM for the strategies used on the units and one-on-one interviews with nurses were held regarding the interventions and their effectiveness.

- Week 10: Evaluation and date collection of nurse participants occurred through post instruments of JSS, ITS and demographic surveys.

\section{Resources and Budget}


Resources required for the project included 40-50 birthday cards, Survey Monkey fees of $\$ 138$ for six months, a positive quotes book, and gift cards of $\$ 5$ for each of the 20 participants, which was part of the budget for nurse participation in the surveys. The statistician was an important resource in obtaining results that maintained the validity and reliability of the project. Four hours was budgeted for the statistician, and a \$150 was included for incidental expenses (see Table 1).

\section{Project Manager}

According to Harris et al. (2020) being an effective communicator will engage others, thereby, providing leverage to initiate and complete projects in a timely manner. Awareness of individuals processing information differently should be acknowledged and planned for in working with diverse workforces. Project managers should also possess planning and organizational skills to keep the project on schedule. The PM establishes the direction and ultimate outcomes of the project and then manages the project effectively to completion. According to Carayon and Wood (2010) skills required for a PM include good communication, the ability to examine human behavior, and effectively interact with others in their surroundings.

The PM led the project with oversight by the CNO. The effect of the PM was evident through the improvement of communication skills such as one-on-one interactions with nursing staff, involvement in conflict resolution, maintaining interventions through leadership change, and the organization of scheduled huddles. The PM designed the acknowledgment and recognition materials for the nurse managers to distribute in the morning huddles, which not only improved morale but also validated to the staff nurses that their contributions were valued. These skills combined with the development of the appreciation materials, achieved the outcome of improving the work environment. 


\section{Results}

\section{Process Measures}

During the implementation phase, there was a change in nurse managers, which did impact the final results of the project. However, the nurse managers who were present with their staff nurses, showed better relationships and set the standard for the importance of respectful and engaging communication in the work environment. In this project, by the nurse managers asking questions, getting into the staff nurses' reality, and dialoging with them, it created a positive atmosphere for constructive criticism (see Table 2).

\section{Statistical Analysis}

Intellectus Statistics (2021) was the software used to conduct statistical analyses and organize the data to determine the impact on the results. The collected data was secured by using passwords, granting only the PM access. Permissions for tools (see Appendices D, E, \& F) were within the public domain. Reliability of JSS was .68 to .91; ITS was .88 to .90 , and demographics .70 to .90 . Validity of JSS was .61 to .81 and ITS was .51 to .84 . Face validity of the demographics was performed by five nurse experts. USAHS and hospital approvals were received. The logic model of the categories of measure are listed in Table 3. A 10\% increase in ITS and JSS post intervention survey data collection was noted as significant. Clinical significance was based on the interventions and their effects on ITS and JSS in the workplace environment.

\section{Demographics}

Frequencies and percentages were calculated for the demographic table (see Table 4) of gender, age, ethnicity, education, years of experience, relationship, and expertise split by time period. For the time period before the intervention (pre-test) to the time period post intervention 
(post-test), males and females were equally represented, each 4 (44\%). For the pre-test data collection, the ages were 20-30 $(n=4,44 \%)$, ethnicity was White or Caucasian $(n=3,33 \%)$, and education was BSN ( $n-=5,56 \%)$, experience was 6 months -1 year $(n=5,56 \%)$, relationship was married $(n=5,56 \%)$, and expertise was proficient and competent, each $3(33 \%)$. The post-test data collection consisted of age, ethnicity, education, years' of experience, relationship, and expertise were missing, each $(n=4,40 \%)$, education at BSN level $(n=4,40 \%)$, relationship was married $(n=4,40 \%)$, expertise was proficient $(n=4,40 \%)$. Some participants did not respond to post demographics if they participated in the pre-test. The demographic frequencies and percentages are presented in detail in Table 4.

\section{Outcome Measures}

A two-tailed independent samples $t$-test was conducted to examine whether the mean of "intent to stay" was significantly different between the pre-test and post-test categories of "time period." The Shapiro-Wilk tests was conducted to determine whether the variables "intent to stay" could have been produced by a normal distribution for each time period (Razali \& Wah, 2011). The result for "intent to stay" in the pre-test category was not significant based on an alpha value of $0.05, W=0.90, p=.248$, suggesting that a normal distribution cannot be ruled out as the underlying distribution for intent to stay in the pre-test category. The result was not significant based on an alpha value of $0.05, W=0.90, p=.345$, suggesting that a normal distribution cannot be ruled out as the underlying distribution for intent to stay in the post-test category. The Shapiro-Wilk test was not significant for either the pre-test or post-test categories of the time period, indicating the normality assumption was met. The Levene's test assessed the data variances. The result for intent to stay was not significant based on an alpha value of $0.05, F$ $(1,14)=0.75, p=.401$. This result suggested it is possible that the variance of intent to stay is 
equal for each category of time period, demonstrating that the assumption of homogeneity of variance was met.

The result of the two-tailed independent samples $t$-test was not significant based on an alpha value of $0.05, t(14)=1.54, p=.145$, indicating the null hypothesis cannot be rejected. This finding suggests the mean of intent to stay was not significantly different between the pretest and post-test categories of the time period (see Table 5). A bar graph of the means is presented in Figure 2 and did reveal clinical significance. Post-test results were a mean of 2.62 from a pre-test mean of 1.77 , indicating a statistically insignificant result. Major changes in nursing management occurred after the implementation of the project that directly affected this acute care unit, and also impacted the implementation of the project. These changes played a role in the statistically insignificant results of this project, however, with consistent management and a larger sample size, the results may yield an outcome with statistical significance.

A two-tailed independent samples $t$-test was conducted to examine whether the mean of "job satisfaction" was significantly different between the pre-test and post-test categories of the time period. Shapiro-Wilk tests were conducted to determine whether job satisfaction could have been produced by a normal distribution for each category of the time period (Razali \& Wah, 2011). The results for job satisfaction in the pre-test category was not significant based on an alpha value of $0.05, W=0.89, p=.291$. This suggested that a normal distribution cannot be ruled out as the underlying distribution for job satisfaction in the pre-test category. The results for job satisfaction in the post-test category was not significant based on an alpha value of $0.05, W=$ $0.95, p=.705$. This suggests that a normal distribution cannot be ruled out as the underlying distribution for job satisfaction in the post-test category. The Shapiro-Wilk test was not 
significant for either the pre-test or post-test categories of the time period, indicating the normality assumption was met.

The Levene's test was conducted to assess whether the variance of job satisfaction was equal between the categories of the time-period. The result for job satisfaction overall was not significant based on an alpha value of $0.05, F(1,15)=0.38, p=.545$. This result suggests it is possible that the variance of job satisfaction is equal for each category of the time period, demonstrating that the assumption of homogeneity of variance was met.

The result of the two-tailed independent samples $t$-test was not significant based on an alpha value of $0.05, t(15)=1.84, p=.085$. This finding suggests the mean of job satisfaction was not significantly different between the pre-test and post-test categories of time period. The results are presented in Table 6. A bar graph of the means is presented in Figure 3 and did reveal clinical significance. The job satisfaction results were post-test mean of 3.10 from pre-test of 3.84, suggesting a statistically insignificant result. A larger sample size may produce results of statistical significance.

\section{Impact}

The intervention increased communication between nurses and nurse managers, as well as the acknowledgement and recognition in the workplace environment. A larger sample size and more time, may impact the unit, with the aim to increase job satisfaction and reduced nurses' intent to leave. Nurse managers implemented the intervention of direct and focused communication that acknowledged and recognized staff performance. Certificates of recognition and acknowledgement (signed by nurse managers) were given to nursing staff, along with cards of appreciation. Within the implementation of 15-minute walking rounds, concerns were found regarding staffing, scheduling, and equipment, which provided areas of improvement 
opportunities to be addressed. Utilization of rounds several times a week is viewed as a continual important aspect and has remained a sustainable outcome. This practice change highlighted the importance of the availability and visibility of nurse managers being present on the units. The clinical significance noted was the resilience of the nurses and hopefulness towards the positive changes of nurse retention interventions.

The sustainability of the project was due to the new management's acceptance of the interventions. Certificates and cards samples were given to management, who stated they will continue to use them. The favorable attitude of the unit and overall environment improved as the nurses felt recognized and acknowledged, as observed by the PM. The ongoing effectiveness of the intervention can continue to be measured using the JSS form and continued rounding by the nurse managers.

\section{Dissemination}

The PM attended a round table discussion by the American Holistic Nurses' Association Practice Committee, which discussed the topic of nurse retention in the workplace. A powerpoint presentation was prepared for the weekly directors meeting, to share the project results with the $\mathrm{CNO}$, preceptor, and other nurse leaders. The evidenced based interventions, methodology, results, strengths, and barriers that were encountered was presented and a video presentation link was sent to those who were unable to attend. An abstract for a poster presentation will be submitted to the American Nurses' Association conference and the American Association of Critical Care Nurses (AACN) conference. The journal manuscript guidelines for the AACN and the American Psychiatric Nurses Association were reviewed for an article submission, and a journal manuscript will be prepared for publication. In addition, an 
application will be submitted to the university's Sigma Theta Tau chapter meeting for consideration of project presentation.

\section{Plans for Sustainability}

The plans for sustainability consists of the nurse managers maintaining their visibility and availability in patient care areas, interacting with staff nurses, acknowledging staff, and giving feedback to staff through open and direct communication. The nurse manager will also continue to lead focus groups, as this became an asset in addressing nurse turnover and retention, as well as, other issues from the staffs' perspective. Another important aspect for sustainability is maintaining a positive workplace environment that values nurse suggestions and recommendations to patient care and increases the voice of nurses in the decision-making process.

\section{Conclusion}

The intention of this project was to evaluate the effect of the implementation of nurse retention strategies and the influence this had on a nurses' job satisfaction and intent to leave their position. This hospital setting did not have any nurse retention strategies in place prior to this project and their nursing turnover rate had significantly increased. Lewin's change model guided nurse management in creating a positive work environment using retention strategies. Literature themes that promoted a positive workplace environment, identified this as having a direct impact on job satisfaction, improved nurse retention, and decreased nurse turnover. A workplace environment that consists of teamwork, effective and intentional communication between staff and management, nurse autonomy, and management who are visible and engaged in their staff, will experience a decrease in nurse turnover and an increase in the retention of nurses (Tang \& Hudson, 2019). 
Nurses are frontline workers caring for patients and their families, and it is vital for nurses to have a sense of job satisfaction and a decrease of intent to leave to continue to provide quality care. Nurse managers who are actively engaged with their nursing staff are instrumental in creating a positive work environment, leading to job satisfaction and an increase in intent to stay, resulting in improved nurse retention (Nurdiana et al., 2018; Tang \& Hudson, 2019). High nurse turnover rates directly affect patient outcomes as organizations are finding it difficult to retain nurses, causing staff shortages, burnout, and increased costs for the organization. Expert nurses are needed to provide quality care to patients, serve as mentors to novice nurses and become involved in decision making on their units. Ongoing nurse retention strategies are needed to improve the workplace environment, job satisfaction, intent to stay, and quality care. 


\section{References}

Adams, A.M.N., Chamberlain, D., \& Giles, T.M. (2019). Understanding how nurse managers see their role supporting ICU nurse well-being-A case study. Journal of Nursing Management, 27, 1512-1521.

Aiken, L. H., Sloane, D., Griffiths, P., Rafferty, A. M., Bruyneel, L., McHugh, M., Maier, C. B., Moreno-Casbas, T., Ball, J.E., Ausserhofer, D., \& Sermeus, W. (2017). Nursing skills mix in European hospitals: Cross-sectional study of the association with mortality, patient ratings, and quality of care. BMJ Quality \& Safety, 26(7), 559-568. https://doi.org/10.1136/bm- jqs-2016-005567 PMID:28626086

Blake, P.G., \& Bacon, C.T. (2020). Structured rounding to improve staff nurse satisfaction with leadership. Nurse Leader, 18(5), 461-466.

Bowles, J. R., Batcheller, J., Adams, J. M., Zimmermann, D., \& Pappas, S. (2019). Nursing’s leadership role in advancing professional practice/wok environments as part of the quadruple aim. Nursing Administration Quarterly, 43(2), 157-163. https://doi.org/10.1097/NAQ.0000000000000342 PMID:30839452

Brook, J., Aitken, L., Webb, R., MacLaren, J., \& Salmon, D. (2019). Characteristics of successful interventions to reduce turnover and increase retention of early career nurses: A systematic review. International Journal of Nursing Studies, 91, 47-59.

Brown, R., Wey, H., \& Foland, K. (2018). The relationship among change fatigue, resilience, and job satisfaction of hospital staff nurses. Journal of Nursing Scholarship, 50(3), 306313.

Carter, M. R. \& Tourangeau, A. E. (2012). Staying in nursing: what factors determine whether nurses intend to remain employed? Journal of Advanced Nursing 68, 1589-1600. 
Coundounaris, D.N., Akuffo, I.N., \& Nkulenu, A.O. (2020). Human resource management for Ghanaian nurses: Job satisfaction versus turnover intentions. Sustainability, 17(7117), 15.

Dang, D., \& Dearholt, S. (2017). Johns Hopkins nursing evidence-based practice: model and guidelines. 3rd ed. Indianapolis, IN: Sigma Theta Tau International.

Dang, D., \& Dearholt, S. (2012). The Johns Hopkins nursing evidence-based practice model and process overview. $2^{\text {nd }}$ ed. Indianapolis, IN: Sigma Theta Tau International.

Dewanto, A., \& Wardhani, V. (2018). Nurse turnover and perceived causes and consequences: A preliminary study at private hospitals in Indonesia. BMC Nursing, 17 (52), p15.

Genly, B. (2016). Safety \& job burnout. Understanding complex contributing factors. Professional Safety, 61(10), 45-49.

Harris, J. L., Roussel, L., Dearman, C. \& Thomas, P. L. (2020). Project planning and management. A guide for nurses and interprofessional teams. Jones and Bartlett, Burlington, MA.

Hogan, A., \& Roberts, B. (2015). Occupational employment projects to 2024. Monthly Labor Bureau Review. U.S. Bureau of Labor Statistics. https://doi.org/10.21916/mlr.2015.49

Hospital Association of Southern California. (2017). Southern California's health care workforce: Challenges, approaches and solutions. https://www.hospitalcouncil.org/sites/main/files/fileattachments/2017hascworkforcereport.pdf?1518644155

Hussein, R., Salamonson, Y., Hu, W., \& Everett, B. (2019). Clinical supervision and ward orientation predict new graduate nurses' intention to work in critical care: Findings from a prospective observational study. Australian Critical Care, 32, 397-402. 
Intellectus Statistics [Online computer software]. (2021). Intellectus Statistics.

https://analyze.intellectusstatistics.com/

Jakimowicz, S., Perry, L., \& Lewis, J. (2018). Compassion satisfaction and fatigue: A crosssectional survey of Australian intensive care nurses. Australian Critical Care, 31(6), 396405. https://doi:10.1016/j.aucc.2017.10.003

Ke, Y-T., \& Hung, C-H. (2017). Predictors of nurses' intent to continue working at their current hospital. Nursing Economics, 35(50, 259-266.

Kleinman, C. T. (2004). The relationship between managerial leadership behaviors and staff nurse retention. Hospital Topics: Research and Perspectives on Healthcare, 82 (4), 8

Labrague, L.J., Nwafor, C.E., \& Tsaras, K. (2020). Influence of toxic and transformational leadership practices on nurses' job satisfaction, job stress, absenteeism and turnover intention: A cross-sectional study. Journal of Nursing Management, 28, 1104-1113.

Laschinger, H.K., Zhu, J., \& Read, E. (2016). New nurses’ perceptions of professional practice behaviors, quality of care, job satisfaction, and career retention. Journal of Nursing Management, 24, 656-665. https://doi.org/10.1111/jonm.12370

Lee, T.S-H., Tzeng, W-C., Chiang, H-H. (2019). Impact of coping strategies on nurses' wellbeing and practice. Journal of Nursing Scholarship, 51(2), 195-204.

Mbemba, G., Gagnon, M.-P., Pare, G., Cote, J., (2013). Interventions for supporting nurse retention in rural and remote areas: An umbrella review. Human Resources Health 11(44).

McCloskey, J.C. (1990). Two requirements for job contentment: Autonomy and social integration. Image: Journal of Nursing Scholarship, 22(3), 140-143. 
Minamizono, S., Nomura, K., Inoue, Y., Hiraike, H., Tsuchiya, A., \& Illing, J. (2019). Gender division of labor, burnout and intention to leave work among young female nurse in Japan: A cross-sectional study. International Journal of Environmental Research and Public Health, 16(12), 12p.

Moisoglou, I., Yfantis, A., Galanis, P., Pispirigou, A., Theoxari, A., Prezerakos, P. (2020). Nurses work environment and patients' quality of care. International Journal of Caring Sciences, 13(1), 108-116.

NSI Nursing Solutions, Inc. (2021). 2020 NSI national health care retention \& RN staffing report. https://www.nsinursingsolutions.com/Documents/Library/NSI_National_Health_Care_R etention_Report.pdf

Nurdiana, N., Hariyati, R. T.S., \& Gayatri, D. (2018). Head nurse strategy for increasing nurse retention: A factor analysis. Enfermeria Clinica, 29(S2), 560-566.

O’Donnell, R. (2019). Hospital turnover in 2018: The trend continues. https://www.hospitalrecruiting.com/blog/5729/hospital-turnover-in-2018-the-trend$\underline{\text { continues }}$

Putra, A.P., Kusnanto, K., Yuwono, S.R. (2020). Effect of job satisfaction and organizational commitment on nurse retention: A systematic review. Indonesian Nursing Journal of Education and Clinic, 5(2), 197-205.

Rivaz, M., Tavakolina, M., Momennasab, M. (2020). Nursing professional practice environment and its relationship with nursing outcomes in intensive care units: a test of the structural equation mode. Scan J. Caring Science. https://doi.org/10.1111/scs.12877 
Semachew, A., Belachew, T., Tesfaye, T., \& Adinew, Y.M. (2017). Predictors of job satisfaction among nurses working in Ethiopian public hospitals, 2014: Institution-based crosssectional study. Human Resources for Health, 15(31), 8p.

Serpa, S., \& Ferreira, C.M. (2019). Micro, meso and macro levels of social analysis. International Journal of Social Science Studies, 7(3), 120-124.

Spector, P.E. (1985). Measurement of human service staff satisfaction: Development of the Job Satisfaction Survey. American Journal of Community Psychology, 13, 693-713.

Spence Laschinger, H. K., \& Fida, R. (2015). Linking nurses' perceptions of patient care quality to job satisfaction: The role of authentic leadership and empowering professional practice environments. The Journal of Nursing Administration, 45(5), 276-283. https://doi.org/10.1097/NNA.0000000000000198PMID:25906136

Strachota, E., Normandin, P., O’Brien, N., Clary, M., \& Krukow, B. (2003) Reasons registered nurses leave or change employment status. Journal of Nursing Administration 33, 111117.

Swanson, D.J. \& Creed, A.S. (2014). Sharpening the focus of force field analysis. Journal of Change Management, 14(1), 28-47. http://dx.doi.org/10.1080/14697017.2013.788052

Tang, J.H.C., \& Hudson, P. (2019). Evidenced-Based Practice guideline, nurse retention for nurse managers. Journal of Gerontological Nursing, 45(11), 12.

Usta, Y. Y. \& Caglar, S. (2016). Strategies and models for evidenced based nursing practice. Recent Advances in Health Sciences, 104.

Van den Bulcke, B, Mextaxa, V., Rusinova, K., Reyners, A.K., Rusinova, K., Jensen, H.I.,Malmgren, J., Darmon, M., Talmor, D., Meert, A., Cancelliere, L., Zubek, L., Maia, P., Michalsen, A., Kompanje, E., Vlerick, P., Roels, J., Vansteelandt, S., Decruyenaere, 
J., ... Benoit, D. (2020). Ethical climate and intention to leave among critical care clinicians: An observational study in 68 intensive care units across Europe and the United States. Intensive Care Medicine, 46(1), 46-56.

Vardaman, J. M., Rogers, B. L., \& Marler, L. E. (2018). Retaining nurses in a changing health care environment: The role of job embeddedness and self-efficacy. Health Care Management Review, 45(1), 52-59.

https://doi:10.1097/HMR.0000000000000202

Whitehead, P.B., Herbertson, R.K., Hamric, A.B., Epstein, E.G. (2015). Moral distress among healthcare professionals: Report of an institution-wide survey. Journal of Nursing Scholarship, 47(2), 117-125.

World Health Organization. (2010). A global survey monitoring progress in nursing and midwifery Available at: WHO, Geneva. www.who.int/hrh/resources/survey/en/

Zander, B., Aiken, L.H., Busse, R., Rafferty, A.M., Sermeus, W., \& Bruyneel, L. (2016). The state of nursing in the European Union. Eurohealth 22(1), 3-6. 


\section{Table 1}

Budget

\section{EXPENSES}

Direct

Project Manager

Advisory Board RNs

Supplies;

All Occasion cards, gift

cards, Achievement

certificates

\section{REVENUE}

\begin{tabular}{lr} 
Billing & 0 \\
\hline Grants & $\$ 1,250.00$ \\
Other funds & $\$ 500.00$ \\
\hline Institutional budget support & $\$ 500.00$
\end{tabular}

$\$ 500.00$

$\$ 720.00$

$\$ 300.00 \quad$ Institutional budget support

$\$ 500.00$

Services

Statistician (4

$\$ 800.00$

hours)

Survey Monkey fees $\quad \$ 138.00$

(6months)

Indirect

Incidentals

$\$ 150.00$

Total Expenses

$\$ 2608.00$ Total Revenue

$\$ 2,250.00$

Net Balance

(\$358.00)




\section{Table 2}

Nursing Leadership Rounding Questions for Engagement

1. What is going well today?

2. Is there anyone I should recognize for exceptional work?

3. Are there any systems that need improvement?

4.Are needed supplies and equipment available?

5. Is there anything I can help with right now?

6. What challenges are you facing in your work?

7. What do you look forward to when you come to work?

8. Is there anything going on in the hospital/unit/organization that you don't understand or would like to know more about?

9. What opportunities do you see for me to improve my leadership on the unit?

10. Can you tell me one thing I could do differently to improve the unit?

11. What issues are important to you?

12. Are there things in your own practice that would improve care on this unit?

Adapted from Blake \& Bacon 2020 


\section{Table 3}

Logic Table

\begin{tabular}{|c|c|c|c|c|c|c|}
\hline Outcomes & Situation & Input & Output & & & \\
\hline $\begin{array}{l}\text { Poor nurse retention. } \\
\text { Strategy of improving } \\
\text { workplace } \\
\text { environment by } \\
\text { communication, } \\
\text { Acknowledgment, } \\
\text { recognition by } \\
\text { engaged nurse } \\
\text { managers to increase } \\
\text { job satisfaction-> } \\
\text { Increased nurse } \\
\text { retention. }\end{array}$ & $\begin{array}{l}\text { Investment: } \\
\text { Managers } \\
\text { Nursing staff } \\
\text { Time } \\
\text { Materials } \\
\text { Money }\end{array}$ & $\begin{array}{l}\text { Activities } \\
\text { Daily rounds: list of } \\
\text { themes from rounds. } \\
\text { Manager led Focus } \\
\text { groups from themes. } \\
\text { Acknowledgements: } \\
\text { verbally, written. } \\
\text { Emails, bulletin } \\
\text { boards, newsletter, } \\
\text { cards. } \\
\text { Inspirational quotes in } \\
\text { meetings. } \\
\text { Recognition in } \\
\text { meetings, verbally, } \\
\text { written (emails, } \\
\text { bulletin boards, } \\
\text { newsletters) of things } \\
\text { done well. }\end{array}$ & $\begin{array}{l}\text { Participation } \\
\text { Nurse managers } \\
\text { Directors } \\
\text { Nursing staff } \\
\text { Interprofessional } \\
\text { Staff }\end{array}$ & $\begin{array}{l}\text { Short term } \\
\text { Focused, directed } \\
\text { Communication } \\
\text { and interactions } \\
\text { between managers } \\
\text { and staff during } \\
\text { daily rounds. } \\
\text { Managers } \\
\text { available and } \\
\text { visible to staff. }\end{array}$ & $\begin{array}{l}\text { Medium Term } \\
\text { Targets staff for } \\
\text { increased } \\
\text { communication/int } \\
\text { eractions. } \\
\text { Increased positive } \\
\text { interactions } \\
\text { between managers } \\
\& \text { staff. } \\
\text { Decrease in call } \\
\text { offs. } \\
\text { Staff problem } \\
\text { solving with } \\
\text { managers. }\end{array}$ & $\begin{array}{l}\text { Long Term } \\
\text { Workplace } \\
\text { environment improved } \\
\text {-> } \\
\text { Increased job } \\
\text { satisfaction-> } \\
\text { Increased nurse } \\
\text { retention. } \\
\text { Sustainability will lead } \\
\text { to financial savings for } \\
\text { hospital due to nurse } \\
\text { retention. }\end{array}$ \\
\hline
\end{tabular}




\section{Table 4}

Demographic Frequencies for Participants

\begin{tabular}{|c|c|c|}
\hline Variable & Pretest & Posttest \\
\hline \multicolumn{3}{|l|}{ Gender } \\
\hline Male & $4(44 \%)$ & $2(20 \%)$ \\
\hline Female & $4(44 \%)$ & $4(40 \%)$ \\
\hline Missing & $1(11 \%)$ & $4(40 \%)$ \\
\hline \multicolumn{3}{|l|}{ Age } \\
\hline $51-64$ & $0(0 \%)$ & $2(20 \%)$ \\
\hline $20-30$ & $4(44 \%)$ & $2(20 \%)$ \\
\hline $41-50$ & $2(22 \%)$ & $0(0 \%)$ \\
\hline $31-40$ & $2(22 \%)$ & $2(20 \%)$ \\
\hline Missing & $1(11 \%)$ & $4(40 \%)$ \\
\hline \multicolumn{3}{|l|}{ Ethnicity } \\
\hline Asian or Asian American & $1(11 \%)$ & $1(10 \%)$ \\
\hline White or Caucasian & $3(33 \%)$ & $3(30 \%)$ \\
\hline Black or African American & $1(11 \%)$ & $2(20 \%)$ \\
\hline American Indian or Alaskan Native & $1(11 \%)$ & $0(0 \%)$ \\
\hline Hispanic/Latino & $1(11 \%)$ & $0(0 \%)$ \\
\hline Asian & $1(11 \%)$ & $0(0 \%)$ \\
\hline Missing & $1(11 \%)$ & $4(40 \%)$ \\
\hline \multicolumn{3}{|l|}{ Education } \\
\hline BSN & $5(56 \%)$ & $4(40 \%)$ \\
\hline AND & $2(22 \%)$ & $2(20 \%)$ \\
\hline Master's Degree & $1(11 \%)$ & $0(0 \%)$ \\
\hline Missing & $1(11 \%)$ & $4(40 \%)$ \\
\hline \multicolumn{3}{|l|}{ Years_experience } \\
\hline $6 \mathrm{mos}-1 \mathrm{yr}$ & $5(56 \%)$ & $1(10 \%)$ \\
\hline $11+$ & $2(22 \%)$ & $3(30 \%)$ \\
\hline $6-10 \mathrm{yrs}$ & $1(11 \%)$ & $1(10 \%)$ \\
\hline $1-3 \mathrm{yrs}$ & $0(0 \%)$ & $1(10 \%)$ \\
\hline Missing & $1(11 \%)$ & $4(40 \%)$ \\
\hline \multicolumn{3}{|l|}{ Relationship } \\
\hline Single & $3(33 \%)$ & $2(20 \%)$ \\
\hline Married & $5(56 \%)$ & $4(40 \%)$ \\
\hline Missing & $1(11 \%)$ & $4(40 \%)$ \\
\hline \multicolumn{3}{|l|}{ Expertise } \\
\hline Advanced beginner & $1(11 \%)$ & $1(10 \%)$ \\
\hline Proficient & $3(33 \%)$ & $4(40 \%)$ \\
\hline Competent & $3(33 \%)$ & $1(10 \%)$ \\
\hline Novice & $1(11 \%)$ & $0(0 \%)$ \\
\hline Missing & $1(11 \%)$ & $4(40 \%)$ \\
\hline
\end{tabular}

Note. Due to rounding errors, column wise percentages may not equal $100 \%$. 


\section{Table 5}

Two-Tailed Independent Samples $t$-Test for intent to stay by time period

\begin{tabular}{cccccccc}
\hline & \multicolumn{2}{c}{ Pretest } & \multicolumn{2}{c}{ Posttest } & & & \\
\cline { 2 - 5 } Variable & $M$ & $S D$ & $M$ & $S D$ & $t$ & $P$ & $D$ \\
\hline intent to stay & 2.62 & 1.26 & 1.77 & 0.82 & 1.54 & .145 & 0.80 \\
\hline
\end{tabular}

Note. $\mathrm{N}=16$. Degrees of Freedom for the $t$-statistic $=14 . d$ represents Cohen's $d$. 


\section{Table 6}

Two-Tailed Independent Samples t-Test for job satisfaction by time period

\begin{tabular}{cccccccc}
\hline & \multicolumn{2}{c}{ Pretest } & \multicolumn{2}{c}{ Posttest } & & & \\
\cline { 2 - 5 } Variable & $M$ & $S D$ & $M$ & $S D$ & $t$ & $P$ & $D$ \\
\hline job satisfaction & 3.84 & 1.03 & 3.10 & 0.64 & 1.84 & .085 & 0.87 \\
\hline
\end{tabular}

Note. $\mathrm{N}=17$. Degrees of Freedom for the $t$-statistic $=15 . d$ represents Cohen's $d$. 


\section{Figure 1}

PRISMA 2009 Flow Diagram
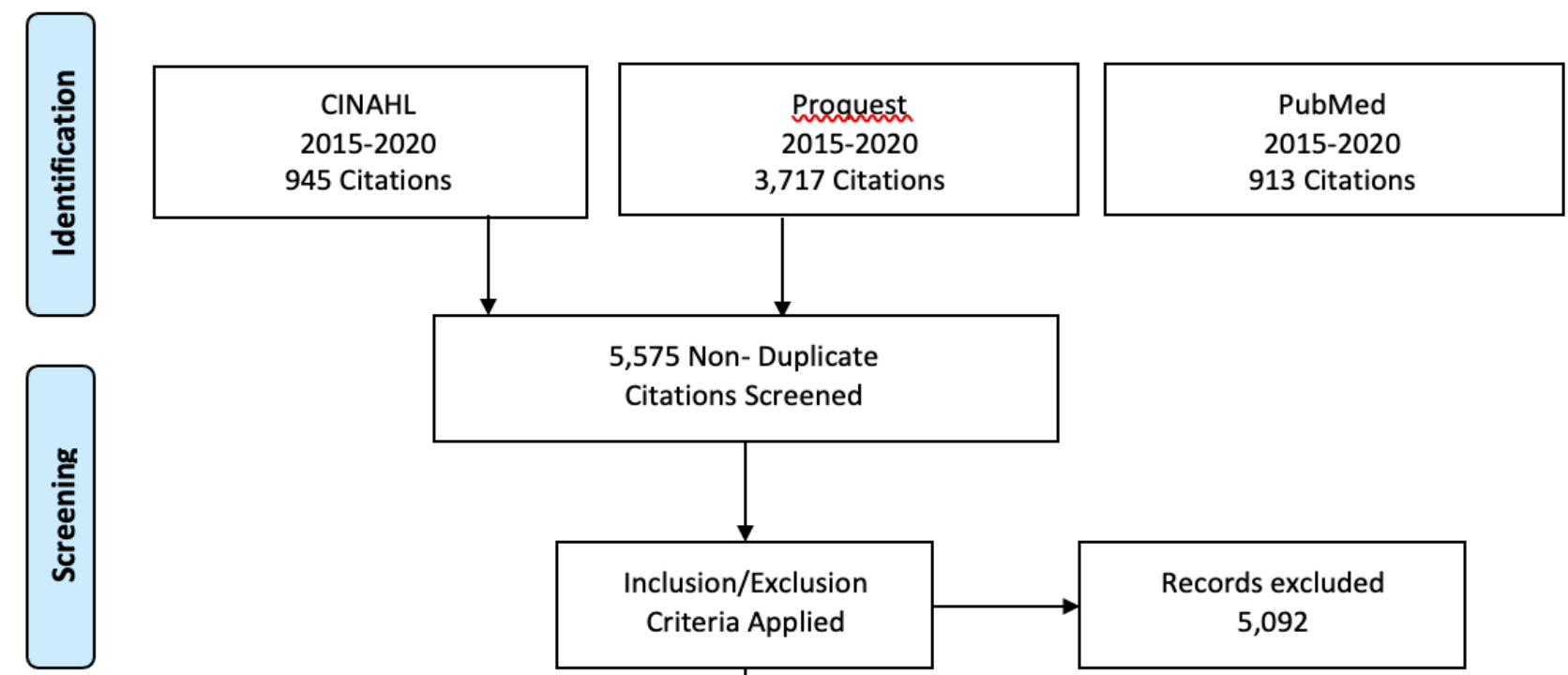

Citations

2015-2020

5,575 Non- Duplicate

Citations Screened

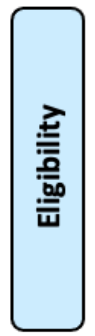

Full-text articles assessed for eligibility 483

Records excluded 5,092

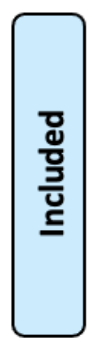

Studies included in synthesis

21 


\section{Figure 2}

The Mean of Intent to Stay by levels of Pre-test and Post-test

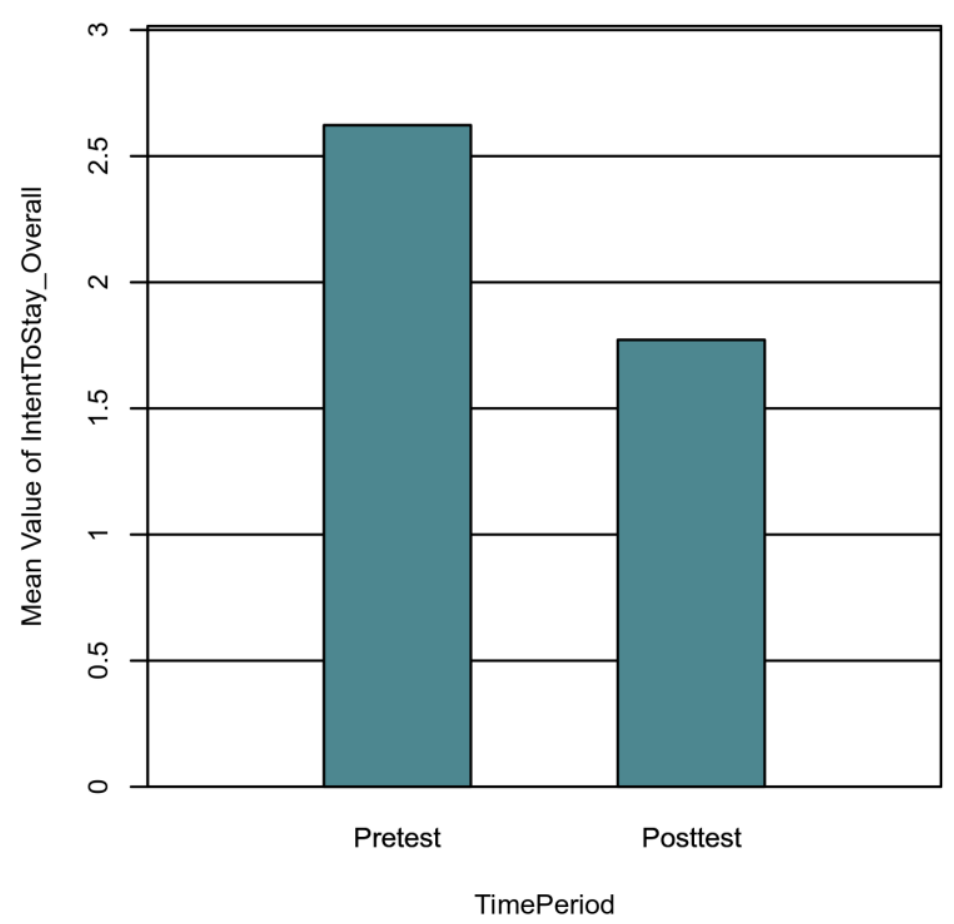


Figure 3

The Mean of Job Satisfaction by Levels of Pre-Test and Post-Test

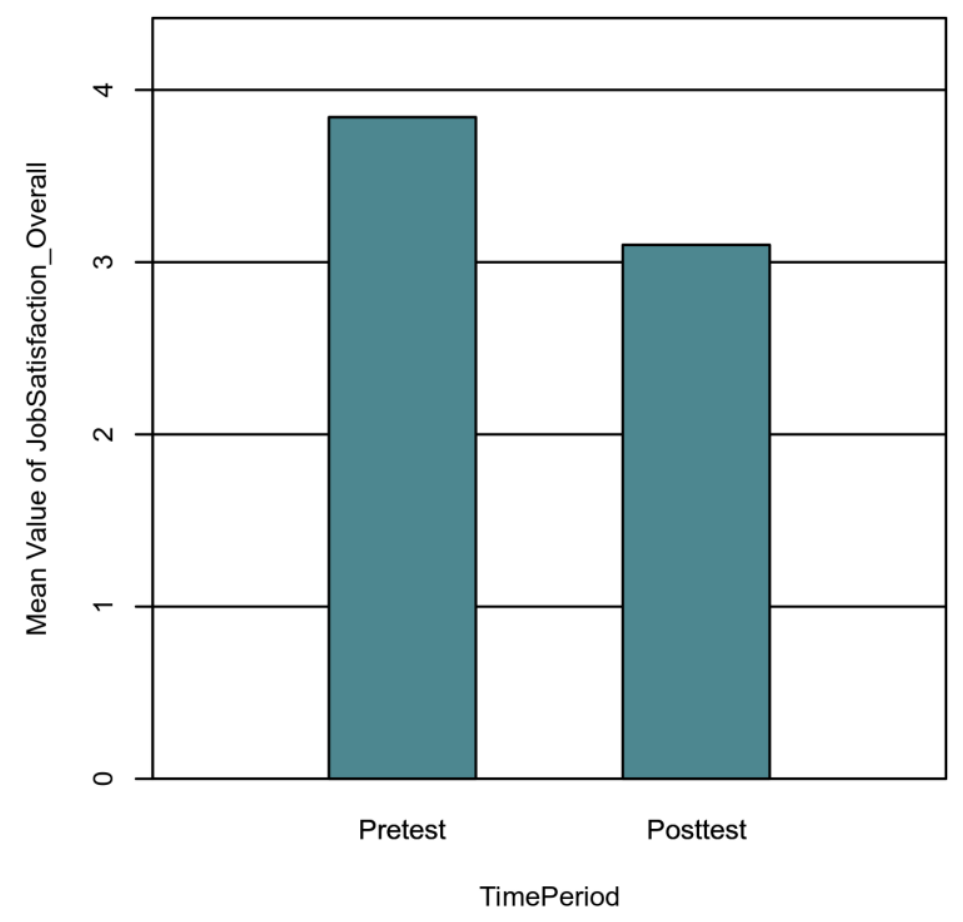





\section{Appendix A}

\section{Summary of Primary Research Evidence}

\begin{tabular}{|c|c|c|c|c|c|c|}
\hline Citation & $\begin{array}{l}\text { Design, } \\
\text { Level } \\
\text { Quality } \\
\text { Grade }\end{array}$ & $\begin{array}{c}\text { Sample } \\
\text { Sample size }\end{array}$ & $\begin{array}{l}\text { Intervention } \\
\text { Comparison } \\
\text { (Definitions } \\
\text { should include } \\
\text { any specific } \\
\text { research tools } \\
\text { used along } \\
\text { with reliability } \\
\text { \& validity) }\end{array}$ & $\begin{array}{l}\text { Theoretical } \\
\text { Foundation }\end{array}$ & $\begin{array}{c}\text { Outcome } \\
\text { Definition }\end{array}$ & $\begin{array}{c}\text { Usefulness } \\
\text { Results } \\
\text { Key Findings }\end{array}$ \\
\hline $\begin{array}{l}\text { Rivaz, M., } \\
\text { Tavakolina, T., } \\
\text { Momennasab.(2020). } \\
\text { Nursing professional } \\
\text { practice environment and } \\
\text { its relationship with } \\
\text { nursing outcomes in } \\
\text { intensive care units: a test } \\
\text { of the structural equation } \\
\text { mode. Scan J. Caring } \\
\text { Science. doi: } \\
\text { 10.1111/scs.12877. Epub } \\
\text { ahead of print. PMID: } \\
\text { 32596858. }\end{array}$ & $\begin{array}{l}\text { Cross- } \\
\text { sectional, } \\
\text { descriptive- } \\
\text { analytical } \\
\text { multi- } \\
\text { centered } \\
\text { study } \\
\text { Level I } \\
\text { Quality } \\
\text { Rating } \\
\text { (QR) =A/B }\end{array}$ & $\begin{array}{l}\text { Stratified } \\
\text { sampling: one } \\
\text { year of work } \\
\text { experience in } \\
\text { ICU \& B.Sc. } \\
320 \text { nurses in } \\
\text { various ICUs }\end{array}$ & $\begin{array}{l}\text { information } \\
\text { form. } \\
\text { Nursing } \\
\text { Professional } \\
\text { Practice } \\
\text { Environment } \\
\text { Questionnaire } \\
\text { (NPPEQ) : } \\
\text { efficient } \\
\text { leadership, } \\
\text { professional } \\
\text { collaboration, } \\
\text { patient } \\
\text { centeredness, } \\
\text { transcendental } \\
\text { professional } \\
\text { climate, } \\
\text { resource } \\
\text { adequacy and } \\
\text { policy } \\
\text { transparency. } \\
\text { Validity by } \\
\text { confirmatory } \\
\text { factor analysis. }\end{array}$ & $\begin{array}{l}\text { Relationship } \\
\text { between nursing } \\
\text { professional } \\
\text { practice } \\
\text { environment with } \\
\text { nurses' burnout } \\
\text { and intention to } \\
\text { leave in intensive } \\
\text { care units, using } \\
\text { structural } \\
\text { equation } \\
\text { modelling } \\
\text { analysis (SEM). }\end{array}$ & $\begin{array}{l}\text { Intention to } \\
\text { leave the } \\
\text { intensive care } \\
\text { units }\end{array}$ & $\begin{array}{l}\text { 1. Burnout strong direct positive } \\
\text { effect on intention to leave. } \\
\text { 2) Severe burnout in two thirds of } \\
\text { ICU } \\
\text { 3)High level of intention to leave. } \\
\text { 4) ICU is stressful. } \\
\text { 5) ICU nurses more prone to } \\
\text { burnout } \\
\text { 6) Positive relationship between } \\
\text { burnout and intention to leave. } \\
\text { 7) Nurses do not intend to leave } \\
\text { with appropriate physician-nurse } \\
\text { relationships, adequate resources, } \\
\text { supportive nursing managers \& } \\
\text { access to information. }\end{array}$ \\
\hline
\end{tabular}




\begin{tabular}{|c|c|c|c|c|c|c|}
\hline $\begin{array}{l}\text { Jakimowicz S, Perry L, } \\
\text { Lewis J. Compassion } \\
\text { satisfaction and fatigue: A } \\
\text { cross-sectional survey } \\
\text { of Australian intensive } \\
\text { care nurses. Aust Crit } \\
\text { Care. } 2018 \\
\text { Nov;31(6):396-405. doi: } \\
\text { 10.1016/j.aucc.2017.10.00 } \\
\text { 3. Epub 2017 Nov } 16 . \\
\text { PMID: } 29153827 \text {. }\end{array}$ & $\begin{array}{l}\text { Mixed } \\
\text { method } \\
\text { study: Cross } \\
\text { sectional } \\
\text { survey \& } \\
\text { interviews } \\
\text { Level II } \\
\text { QR =B }\end{array}$ & $\begin{array}{l}107 \text { Nurses in } \\
\text { Site A. } 93 \\
\text { Nurse in Site } \\
\text { B. Minimum } \\
6 \text { months } \\
\text { experience. }\end{array}$ & $\begin{array}{l}\text { Demographic } \\
\text { Maslash } \\
\text { Burnout } \\
\text { Inventory } \\
\text { (MBI) : Validity } \\
\text { by Cronbach's } \\
\text { alpha } \\
\text { coefficient. } \\
\text { Anticipated } \\
\text { Turnover Scale } \\
\text { (ATS) : Validity } \\
\text { by Cronbach's } \\
\text { alpha } \\
\text { coefficient. } \\
\text { Composite } \\
\text { reliability: } 0.78 \\
\text { - 0.86 for the } \\
\text { three } \\
\text { instruments. } \\
\text { Professional } \\
\text { Quality of Life } \\
\text { Scale version } 5 \\
\text { (PROQOL5). } \\
\text { Demographic } \\
\text { and } \\
\text { occupational } \\
\text { data. }\end{array}$ & $\begin{array}{l}\text { Examine factors } \\
\text { predicting and } \\
\text { contributing to } \\
\text { compassion } \\
\text { satisfaction and } \\
\text { compassion } \\
\text { fatigue in ICUs in } \\
\text { Australia. }\end{array}$ & $\begin{array}{l}\text { Relationships } \\
\text { with } \\
\text { compassion } \\
\text { satisfaction, } \\
\text { burnout and } \\
\text { secondary } \\
\text { traumatic stress } \\
\text { (STS) scores. }\end{array}$ & $\begin{array}{l}\text { 1)Years of practice, tenure, educ } \\
\text { level and place of work influenced } \\
\text { compassion satisfaction and fatigue. } \\
\text { 2) Less experienced nurses had } \\
\text { lower compassion satisfaction; more } \\
\text { vulnerable to burnout than older } \\
\text { tenured nurses. } \\
\text { 3)Working conditions, ethical } \\
\text { dilemmas, and inability to provide } \\
\text { the desired type of nursing care } \\
\text { impact intention to leave of early } \\
\text { 4) Nurses with more experience had } \\
\text { a higher level of compassion } \\
\text { satisfaction. } \\
\text { 5)Management support, } \\
\text { collaboration, engagement and } \\
\text { compassion satisfaction influenced } \\
\text { nurses' decision to remain or leave } \\
\text { the ICU. }\end{array}$ \\
\hline
\end{tabular}




\begin{tabular}{|c|c|c|c|c|c|c|}
\hline $\begin{array}{l}\text { H.I., et al. (2020). Ethical } \\
\text { climate and intention to } \\
\text { leave among critical care } \\
\text { clinicians: An } \\
\text { observational study in } 68 \\
\text { intensive care units across } \\
\text { Europe and the United } \\
\text { States. Intensive Care } \\
\text { Medicine, } 46 \text { (1), 46-56. }\end{array}$ & $\begin{array}{l}\text { questionnair } \\
\text { e. } \\
\text { DISPROPRI } \\
\text { CUS sub - } \\
\text { study. } \\
\text { Level I } \\
\text { QR=A }\end{array}$ & $\begin{array}{l}\text { physicians in } \\
\text { ICUs. }\end{array}$ & $\begin{array}{l}\text { Questionnaire } \\
\text { (EDMCQ). } 68 \\
\text { ICUs in } 12 \\
\text { European } \\
\text { countries and } \\
\text { the U.S. } \\
\text { surveyed. }\end{array}$ & $\begin{array}{l}\text { ICU is associated } \\
\text { with the intention } \\
\text { to leave. }\end{array}$ & $\begin{array}{l}\text { intent to leave } \\
\text { and the quality } \\
\text { of the ethical } \\
\text { climate in ICU. }\end{array}$ & $\begin{array}{l}\text { 2) Lack of collaboration, } \\
\text { disrespectful communication and } \\
\text { distrust among team members are } \\
\text { direct factors of increased job } \\
\text { dissatisfaction and moral distress in } \\
\text { ICU. } \\
\text { 3)Moving from pure knowledge- } \\
\text { based discussions to more } \\
\text { knowledge and value-based } \\
\text { reflections may help to reduce } \\
\text { clinicians' moral distress. }\end{array}$ \\
\hline $\begin{array}{l}\text { Moisoglou, I., Yfantis, A., } \\
\text { Galanis, P., Pispirigou, A., } \\
\text { Theoxari, A., Prezerakos, } \\
\text { P. (2020). Nurses work } \\
\text { environment and patients' } \\
\text { quality of care. } \\
\text { International Journal of } \\
\text { Caring Sciences, } 13 \text { (1), } \\
\text { 108-116. }\end{array}$ & $\begin{array}{l}\text { Cross } \\
\text { sectional } \\
\text { study. } \\
\text { Level I } \\
\text { QR = A }\end{array}$ & $\begin{array}{l}\text { Convenience } \\
\text { sample of } 520 \\
\text { nurses from } 5 \\
\text { public general } \\
\text { hospitals. } 432 \\
\text { completed } \\
\text { surveys } \\
\text { collected. }\end{array}$ & $\begin{array}{l}\text { Practice } \\
\text { Environment } \\
\text { Scale of the } \\
\text { Nursing Work } \\
\text { Index (PES- } \\
\text { NWI) for } \\
\text { assessment of } \\
\text { work } \\
\text { environment. }\end{array}$ & $\begin{array}{l}\text { To assess the } \\
\text { work } \\
\text { environment of } \\
\text { the nurses and } \\
\text { investigate the } \\
\text { relation between } \\
\text { work } \\
\text { environment and } \\
\text { selected patients' } \\
\text { safety indicators. }\end{array}$ & $\begin{array}{c}\text { Nurses work in } \\
\text { a non-favorable } \\
\text { work } \\
\text { environment. }\end{array}$ & $\begin{array}{l}\text { 1)Low PES-NWI for work } \\
\text { environment characteristics staffing, } \\
\text { resource adequacy, nursing } \\
\text { foundations for quality of care and } \\
\text { nurse participation in hospital } \\
\text { affairs. 2) Nursing staff is most } \\
\text { important variable for the provision } \\
\text { of quality and safe healthcare } \\
\text { services. 3) Nurse manager's ability } \\
\text { and leadership and collegial nurse- } \\
\text { physician relations are two } \\
\text { important variables in to provide } \\
\text { quality health services. 4) Nurses } \\
\text { that have good relations with } \\
\text { doctors are more satisfied with their } \\
\text { job and decision making. }\end{array}$ \\
\hline $\begin{array}{l}\text { Lee, T.S-H., Tzeng, W-C., } \\
\text { Chiang, H-H. (2019). } \\
\text { Impact of coping strategies } \\
\text { on nurses' well-being and } \\
\text { practice. Journal of } \\
\text { Nursing Scholarship, } \\
\text { 51(2), 195-204. }\end{array}$ & $\begin{array}{l}\text { Cross } \\
\text { sectional } \\
\text { design: self- } \\
\text { reporting } \\
\text { questionnair } \\
\text { es. } \\
\text { Level I } \\
\text { QR = A }\end{array}$ & $\begin{array}{l}500 \\
\text { participants } \\
\text { randomly } \\
\text { selected from } \\
1350 \text { bed } \\
\text { medical } \\
\text { center in } \\
\text { Taipei, } \\
\text { Taiwan. } 474 \\
\text { returned } \\
\text { questionnaires }\end{array}$ & $\begin{array}{l}\text { Coping } \\
\text { strategies (Brief } \\
\text { COPE), } \\
\text { psychological } \\
\text { well-being } \\
\text { (Ryff's } \\
\text { Psychological } \\
\text { Well-being } \\
\text { Scale), nurses' } \\
\text { practice } \\
\text { environments } \\
\text { (Practice } \\
\text { Environment of }\end{array}$ & $\begin{array}{l}\text { Examine coping } \\
\text { strategies on } \\
\text { nurses' } \\
\text { psychological } \\
\text { well-being, } \\
\text { practice } \\
\text { environments and } \\
\text { safety attitudes. }\end{array}$ & $\begin{array}{l}\text { Distinct } \\
\text { pathway for the } \\
\text { relationships } \\
\text { between } \\
\text { clinical nurses' } \\
\text { psychological } \\
\text { well-being, } \\
\text { practice } \\
\text { environment } \\
\text { and safety } \\
\text { attitudes. }\end{array}$ & $\begin{array}{l}\text { 1) Approach-oriented coping } \\
\text { strategies have significant positive } \\
\text { effects on psychological well-being, } \\
\text { patient safety. 2)Avoidant coping } \\
\text { strategies have the opposite effect. } \\
\text { 3)Intervention to promote } \\
\text { psychological well-being may be } \\
\text { valuable in promoting a positive } \\
\text { nursing practice environment and } \\
\text { patient safety. }\end{array}$ \\
\hline
\end{tabular}




\begin{tabular}{|c|c|c|c|c|c|c|}
\hline & & & $\begin{array}{l}\text { the Nursing } \\
\text { Work Index) } \\
\text { and safety } \\
\text { attitudes (Safety } \\
\text { Attitudes } \\
\text { Questionnaire). }\end{array}$ & & & \\
\hline $\begin{array}{l}\text { Dewanto, A., Wardhani, } \\
\text { V. (2018). Nurse turnover } \\
\text { and perceived causes and } \\
\text { consequences: A } \\
\text { preliminary study at } \\
\text { private hospitals in } \\
\text { Indonesia. BMC Nursing, } \\
17 \text { (Suppl 2):52, 15p. }\end{array}$ & $\begin{array}{l}\text { Survey } \\
\text { method of } \\
\text { human } \\
\text { resources } \\
\text { data, } \\
\text { hospital } \\
\text { managers } \\
\text { surveyed. } \\
\text { Level I } \\
\text { QR = A }\end{array}$ & $\begin{array}{l}515 \text { nurses } \\
\text { surveyed over } \\
1 \text { year period. }\end{array}$ & $\begin{array}{l}\text { Human resource } \\
\text { data utilized } \\
\text { plus an online } \\
\text { survey } \\
\text { regarding } \\
\text { hospital alumni } \\
\text { by hospital } \\
\text { managers. }\end{array}$ & $\begin{array}{l}\text { Description of } \\
\text { nurse turnover } \\
\text { pattern, as } \\
\text { perceived by } \\
\text { hospital } \\
\text { managers. }\end{array}$ & $\begin{array}{l}\text { Nurse turnover } \\
\text { is higher than } \\
\text { the acceptable } \\
\text { level predicted } \\
\text { by age, marital } \\
\text { status and job } \\
\text { tenure. }\end{array}$ & $\begin{array}{l}\text { 1) Common reasons nurses leave: } \\
\text { personal reasons, job offers from } \\
\text { hospitals or other organizations and } \\
\text { working conditions. } \\
\text { 2)Potential way to reduce turnover } \\
\text { is to retain nurses in an organization } \\
\text { more than three years. } \\
\text { 3) Hospital management view } \\
\text { turnover as a disturbance to hospital } \\
\text { services, staffing practices, } \\
\text { managerial processes, and hospital } \\
\text { revenue which increases costs. }\end{array}$ \\
\hline $\begin{array}{l}\text { Coundounaris, D.N., } \\
\text { Akuffo, I.N., \& Nkulenu, } \\
\text { A.O. (2020). Human } \\
\text { resource management for } \\
\text { Ghanaian nurses: Job } \\
\text { satisfaction versus } \\
\text { turnover intentions. } \\
\text { Sustainability, } 17 \text { (7117), } \\
\text { 15p. }\end{array}$ & $\begin{array}{l}\text { Survey of } \\
163 \text { nurses } \\
\text { by } \\
\text { questionnair } \\
\text { es. } \\
\text { Level II } \\
\text { QR=B }\end{array}$ & $\begin{array}{l}163 \\
\text { completed } \\
\text { questionnaires } \\
\text { by nurses in } \\
\text { two private } \\
\text { and two } \\
\text { public } \\
\text { hospitals in } \\
\text { Accra, Ghana. }\end{array}$ & $\begin{array}{l}\text { Questionnaire } \\
\text { consisted of } \\
\text { demographics } \\
\text { and statements } \\
\text { on pay level, } \\
\text { pay raise, } \\
\text { benefits, pay } \\
\text { structure/admini } \\
\text { stration, job } \\
\text { satisfaction \& } \\
\text { turnover } \\
\text { intentions. } \\
\text { Average } \\
\text { Reliability } \\
\text { 0.834 (high). } \\
\text { Convergent } \\
\text { validity }<0.5 \text {. }\end{array}$ & $\begin{array}{l}\text { Exploration of } \\
\text { turnover } \\
\text { intentions and job } \\
\text { satisfaction of } \\
\text { nurses. }\end{array}$ & $\begin{array}{l}\text { The influence } \\
\text { of pay level, } \\
\text { pay } \\
\text { structure/admin } \\
\text { istration and } \\
\text { pay rise have } \\
\text { the most } \\
\text { important } \\
\text { effect on } \\
\text { nurses' job } \\
\text { satisfaction. }\end{array}$ & $\begin{array}{l}\text { 1) Pay rise, pay } \\
\text { structure/administration and job } \\
\text { satisfaction were significantly and } \\
\text { negatively related to turnover } \\
\text { intentions. } \\
\text { 2) Effect of benefits on turnover } \\
\text { intentions was nonsignificant. } \\
\text { 3)Pay level, pay } \\
\text { structure/administration and pay rise } \\
\text { has the most important effect on } \\
\text { nurses' satisfaction. } \\
\text { 4) Age status had negative and } \\
\text { significant effects on turnover } \\
\text { intentions. } \\
\text { 5) Gender status had nonsignificant } \\
\text { impact on turnover intentions. }\end{array}$ \\
\hline $\begin{array}{l}\text { Brown, R., Wey, H., \& } \\
\text { Foland, K. (2018). The } \\
\text { relationship among change } \\
\text { fatigue, resilience, and job } \\
\text { satisfaction of hospital }\end{array}$ & $\begin{array}{l}\text { Descriptive } \\
\text { correlational } \\
\text { design with } \\
521 \text { nurses } \\
\text { with three }\end{array}$ & $\begin{array}{l}521 \text { full \& } \\
\text { part-time staff } \\
\text { nurses with } \\
\text { diploma, } \\
\text { associate, }\end{array}$ & $\begin{array}{l}\text { Three online } \\
\text { surveys } \\
\text { completed by } \\
521 \text { nurses: } \\
\text { Change Fatigue }\end{array}$ & $\begin{array}{l}\text { Examination of } \\
\text { relationship } \\
\text { between change } \\
\text { fatigue, } \\
\text { resilience, and }\end{array}$ & $\begin{array}{l}\text { Job satisfaction } \\
\text { is negatively } \\
\text { influenced by } \\
\text { change fatigue, } \\
\text { positively }\end{array}$ & $\begin{array}{l}\text { 1) Change fatigue may be increased } \\
\text { by larger hospital size (number of } \\
\text { beds). }\end{array}$ \\
\hline
\end{tabular}




\begin{tabular}{|c|c|c|c|c|c|c|}
\hline $\begin{array}{l}\text { staff nurses. Journal of } \\
\text { Nursing Scholarship, } \\
\text { 50(3), 306-313. }\end{array}$ & $\begin{array}{l}\text { online } \\
\text { surveys. } \\
\text { Level I } \\
\text { QR = A }\end{array}$ & $\begin{array}{l}\text { baccalaureate } \\
\text { or master's } \\
\text { degree. }\end{array}$ & $\begin{array}{l}\text { Scale (CFS), } \\
\text { Connor- } \\
\text { Davidson } \\
\text { Resilience Scale } \\
\text { (CDRS), } \\
\text { McCloskey/Mu } \\
\text { eller } \\
\text { Satisfaction } \\
\text { Scale (MMSS). }\end{array}$ & $\begin{array}{l}\text { job satisfaction } \\
\text { among novice } \\
\text { and seasoned } \\
\text { hospital nurses. }\end{array}$ & $\begin{array}{l}\text { influenced by } \\
\text { resilience. }\end{array}$ & $\begin{array}{l}\text { 2) Resilience may be increased by } \\
\text { higher educational level of hospital } \\
\text { staff nurses. } \\
\text { 3) Engaging in strategies to prevent } \\
\text { change fatigue can enhance } \\
\text { workplace environments, job } \\
\text { satisfaction and retention of nurses. }\end{array}$ \\
\hline $\begin{array}{l}\text { Semachew, A., Belachew, } \\
\text { T., Tesfaye, T., \& Adinew, } \\
\text { Y.M. (2017). Predictors of } \\
\text { job satisfaction among } \\
\text { nurses working in } \\
\text { Ethiopian public hospitals, } \\
\text { 2014: Institution-based } \\
\text { cross-sectional study. } \\
\text { Human Resources for } \\
\text { Health, 15(31), 8p. }\end{array}$ & $\begin{array}{l}\text { Institution- } \\
\text { based census } \\
\text { among } 316 \\
\text { nurses with } \\
\text { self- } \\
\text { administered } \\
\text { questionnair } \\
\text { es. } \\
\text { Level II. } \\
\text { QR = A. }\end{array}$ & $\begin{array}{l}316 \text { Jimma, } \\
\text { Ethiopia } \\
\text { public } \\
\text { hospital } \\
\text { nurses } \\
\text { surveyed. } \\
\text { Work } \\
\text { experience of } \\
6 \text { months or } \\
\text { greater. }\end{array}$ & $\begin{array}{l}\text { Data collected } \\
\text { from: 1) Socio- } \\
\text { demographic } \\
\text { questionnaires. } \\
\text { 2)McCloskey/ } \\
\text { Mueller } \\
\text { Satisfaction } \\
\text { Scale (MMSS). } \\
\text { 3) Nurse- } \\
\text { communication } \\
\text { related factors. } \\
\text { 4)Job stress- } \\
\text { related factors. } \\
\text { 5) Professional } \\
\text { commitment } \\
\text { factors. }\end{array}$ & $\begin{array}{l}\text { To assess job } \\
\text { satisfaction and } \\
\text { factors } \\
\text { influencing it } \\
\text { among nurses in } \\
\text { Jimma, Ethiopia } \\
\text { public hospitals. }\end{array}$ & $\begin{array}{l}\text { One third of } \\
\text { nurses had a } \\
\text { low level of job } \\
\text { satisfaction. }\end{array}$ & $\begin{array}{l}\text { 1) Professional commitment, } \\
\text { workload, working unit, and mutual } \\
\text { understanding at work predicted the } \\
\text { outcome variable. } \\
\text { 2) Individuals with high levels of } \\
\text { professional commitment are more } \\
\text { likely to engage in activities that } \\
\text { favor the organization. }\end{array}$ \\
\hline $\begin{array}{l}\text { Labrague, L.J., Nwafor, } \\
\text { C.E., \& Tsaras, K. (2020). } \\
\text { Influence of toxic and } \\
\text { transformational } \\
\text { leadership practices on } \\
\text { nurses' job satisfaction, } \\
\text { job stress, absenteeism and } \\
\text { turnover intention: A } \\
\text { cross-sectional study. } \\
\text { Journal of Nursing } \\
\text { Management, } 28,1104- \\
1113 .\end{array}$ & $\begin{array}{l}\text { Cross- } \\
\text { sectional } \\
\text { study of } \\
770 \\
\text { registered } \\
\text { nurses. } \\
\text { Level I } \\
\text { QR = A }\end{array}$ & $\begin{array}{l}\text { Data was } \\
\text { collected from } \\
770 \text { registered } \\
\text { nurses from } \\
15 \text { hospitals } \\
\text { in Central } \\
\text { Philippines } \\
\text { using seven } \\
\text { self-report } \\
\text { scales. Nurses } \\
\text { have } \\
\text { minimum of } \\
\text { six months' } \\
\text { work } \\
\text { experience. }\end{array}$ & $\begin{array}{l}\text { Instrumentation } \\
\text { used: 1) Toxic } \\
\text { Leadership } \\
\text { Behaviors of } \\
\text { Nurse Managers } \\
\text { Scale (ToxBH- } \\
\text { NM), validity } \\
\text { index 0.96, } \\
\text { Reliability } \\
\text { Cronbach } \alpha \text { of } \\
\text { 98. } \\
\text { 2) Global } \\
\text { Transformation } \\
\text { al Leadership } \\
\text { Scale (GTL), }\end{array}$ & $\begin{array}{l}\text { Examine the } \\
\text { influence of toxic } \\
\text { and } \\
\text { transformational } \\
\text { leadership } \\
\text { practices on } \\
\text { nurses' job } \\
\text { satisfaction, } \\
\text { psychological } \\
\text { distress, } \\
\text { absenteeism, and } \\
\text { intent to leave the } \\
\text { organization or } \\
\text { nursing } \\
\text { profession. }\end{array}$ & $\begin{array}{l}\text { Nurses who } \\
\text { work for } \\
\text { managers } \\
\text { exhibiting toxic } \\
\text { leadership } \\
\text { behaviors } \\
\text { demonstrate } \\
\text { lower job } \\
\text { contentment, } \\
\text { higher stress } \\
\text { levels, frequent } \\
\text { absenteeism } \\
\text { and higher } \\
\text { intent to leave }\end{array}$ & $\begin{array}{l}\text { 1) Nurses working with } \\
\text { transformational leaders report } \\
\text { higher job contentment and lower } \\
\text { intent to the leave the nursing } \\
\text { profession. } \\
\text { 2) Nurse retention strategies should } \\
\text { include measures to foster } \\
\text { transformational leadership and } \\
\text { derail toxic leadership practices } \\
\text { through evidence-based education, } \\
\text { training and professional } \\
\text { development. }\end{array}$ \\
\hline
\end{tabular}




\begin{tabular}{|c|c|c|c|c|c|c|}
\hline & & & $\begin{array}{l}\text { Cronbach } \alpha \text { of } \\
.91 . \\
\text { 3) Job } \\
\text { Satisfaction } \\
\text { Index (JS), } \\
\text { Cronbach } \alpha \text { of } \\
.81 . \\
\text { 4) Perceived } \\
\text { Stress Scale } \\
\text { (PSS), } \\
\text { Cronbach } \alpha \text { of } \\
\text {.89. } \\
\text { 5) Two single } \\
\text { item measures } \\
\text { for turnover } \\
\text { retention. } \\
\text { Reliability } 0.92 \\
\text { and } 0.91 . \\
\text { 6) Single item } \\
\text { measure to } \\
\text { capture } \\
\text { absenteeism. } \\
\text { Reliability } \alpha \\
\text { =.89 }\end{array}$ & & $\begin{array}{l}\text { the nursing } \\
\text { profession. }\end{array}$ & \\
\hline $\begin{array}{l}\text { Nurdiana, N., Hariyati, R. } \\
\text { T.S., \& Gayatri, D. (2018). } \\
\text { Head nurse strategy for } \\
\text { increasing nurse retention: } \\
\text { A factor analysis. } \\
\text { Enfermeria Clinica, } 29 \\
\text { (S2), 560-566. }\end{array}$ & $\begin{array}{l}\text { Descriptive } \\
\text { research } \\
\text { using cross- } \\
\text { sectional } \\
\text { approach. } \\
\text { Level I } \\
\text { QR = A }\end{array}$ & $\begin{array}{l}\text { Sample of } 99 \\
\text { head nurses in } \\
\text { general } \\
\text { hospitals in } \\
\text { Jakarta, } \\
\text { Indonesia. }\end{array}$ & $\begin{array}{l}\text { Four research } \\
\text { questionnaires } \\
\text { used: } \\
\text { 1) } \\
\text { Demographics } \\
\text { of head nurses. } \\
\text { 2) Knowledge } \\
\text { of nurse } \\
\text { retention. } \\
\text { 3) Effectiveness } \\
\text { of retention } \\
\text { strategies. } \\
\text { Validity ( } \mathrm{r}= \\
\text { 0.338-0.744). } \\
\text { 4) Factors } \\
\text { affecting }\end{array}$ & $\begin{array}{l}\text { To identify } \\
\text { factors that may } \\
\text { influence } \\
\text { strategies for } \\
\text { increasing nurse } \\
\text { retention. }\end{array}$ & $\begin{array}{l}\text { Nurse retention } \\
\text { strategies } \\
\text { employed by } \\
\text { the head nurse } \\
\text { need strong } \\
\text { support from } \\
\text { hospital } \\
\text { management to } \\
\text { achieve success } \\
\text { in improving } \\
\text { nurse retention } \\
\text { international } \\
\text { databases. }\end{array}$ & $\begin{array}{l}\text { 1) Good leadership support and } \\
\text { staffing function have the potential } \\
\text { to increase the effectiveness of a } \\
\text { retention strategy as much as } \\
37.84 \% \text { compared with less } \\
\text { effective leadership support and } \\
\text { staffing function. } \\
\text { 2)Other influencing factors are } \\
\text { organizational factors and } \\
\text { performance of the head nurse. } \\
\text { 3)Workload, saturation, leadership, } \\
\text { opportunities for improvement, role } \\
\text { clarity, achievement, recognition } \\
\text { and work environment are } \\
\text { individual nursing staff factors. }\end{array}$ \\
\hline
\end{tabular}




\begin{tabular}{|c|c|c|c|c|c|c|}
\hline & & & $\begin{array}{l}\text { retention } \\
\text { strategies. } \\
\text { Validity (r } \\
>0.202)\end{array}$ & & & \\
\hline $\begin{array}{l}\text { Adams, A.M.N., } \\
\text { Chamberlain, D., \& Giles, } \\
\text { T.M. (2019). } \\
\text { Understanding how nurse } \\
\text { managers see their role } \\
\text { supporting ICU nurse } \\
\text { well-being-A case study. } \\
\text { Journal of Nursing } \\
\text { Management, } 27,1512- \\
\text { 1521. }\end{array}$ & $\begin{array}{l}\text { Qualitative } \\
\text { multiple } \\
\text { case study } \\
\text { design. } \\
\text { Twelve } \\
\text { semi- } \\
\text { structured, } \\
\text { in-depth } \\
\text { interviews } \\
\text { with nurse } \\
\text { managers. } \\
\text { Level II } \\
\text { QR = B }\end{array}$ & $\begin{array}{l}\text { Twelve } \\
\text { participants } \\
\text { from one } \\
\text { Australian } \\
\text { territory and } \\
\text { five states, } 10 \\
\text { females, aged } \\
32-60 \text { years. }\end{array}$ & $\begin{array}{l}\text { Semi-structured } \\
\text { interviews } \\
\text { offered face-to- } \\
\text { face, online or } \\
\text { via telephone. } \\
\text { All interviews } \\
\text { were audio- } \\
\text { recorded and } \\
\text { lasted } 45 \text { to } 70 \\
\text { minutes. }\end{array}$ & $\begin{array}{l}\text { To explore how } \\
\text { nurse managers } \\
\text { perceive and } \\
\text { experience their } \\
\text { role in supporting } \\
\text { the well-being of } \\
\text { ICU nurses. }\end{array}$ & $\begin{array}{l}\text { Currently no } \\
\text { consensus on } \\
\text { the role of the } \\
\text { nurse manager } \\
\text { in supporting } \\
\text { nurse well- } \\
\text { being. }\end{array}$ & $\begin{array}{l}\text { 1) No consensus on role of the nurse } \\
\text { manager in supporting the well- } \\
\text { being of ICU nurses. } \\
\text { 2) Nurse managers felt unsure about } \\
\text { what their supportive role entailed. } \\
\text { 3) There are strategies that enabled } \\
\text { nurse managers to support nurse } \\
\text { well-being. }\end{array}$ \\
\hline $\begin{array}{l}\text { Tang, J.H-C., \& Hudson, } \\
\text { P. (2019). Nurse retention } \\
\text { for nurse managers. } \\
\text { Journal of Gerontological } \\
\text { Nursing, 45(11),11-19. }\end{array}$ & $\begin{array}{l}\text { Evidence- } \\
\text { based } \\
\text { practice } \\
\text { guideline. } \\
\text { Level IV } \\
\mathrm{QR}=\mathrm{A}\end{array}$ & $\begin{array}{l}\text { Guideline for } \\
\text { first line nurse } \\
\text { managers } \\
\text { using } \\
\text { literature } \\
\text { search. }\end{array}$ & $\begin{array}{l}\text { 1)Nurse } \\
\text { Turnover } \\
\text { Measurement } \\
\text { form } \\
\text { 2) Demographic } \\
\text { information. } \\
\text { 3) Price Job } \\
\text { satisfaction } \\
\text { Scale. } \\
\text { 4) McCain's } \\
\text { Intent to Stay } \\
\text { Scale. }\end{array}$ & $\begin{array}{l}\text { Interventions to } \\
\text { of autonomy, } \\
\text { recognition and } \\
\text { communication to } \\
\text { aid nurse } \\
\text { managers in } \\
\text { enhancing job } \\
\text { satisfaction and } \\
\text { decreasing } \\
\text { turnover of staff } \\
\text { nurses. }\end{array}$ & $\begin{array}{l}\text { Retaining } \\
\text { expert nurses } \\
\text { will have a } \\
\text { positive effect } \\
\text { on quality } \\
\text { patient care. }\end{array}$ & $\begin{array}{l}\text { 1) Enhance nurses' autonomy } \\
\text { 2) Allow staff nurses to have more } \\
\text { control over their work. } \\
\text { 3) Increase involvement of staff } \\
\text { nurses in decision making that } \\
\text { affects nursing practice. } \\
\text { 4)Promote shared governance. } \\
\text { 5)Demonstrate recognition and } \\
\text { respect to nurses. } \\
\text { 6) Improve communication with } \\
\text { staff nurses. }\end{array}$ \\
\hline $\begin{array}{l}\text { Whitehead, P.B., } \\
\text { Herbertson, R.K., Hamric, } \\
\text { A.B., Epstein, E.G. } \\
\text { (2015). Moral distress } \\
\text { among healthcare } \\
\text { professionals: Report of an } \\
\text { institution-wide survey. } \\
\text { Journal of Nursing } \\
\text { Scholarship, 47(2), 117- } \\
\text { 125. }\end{array}$ & $\begin{array}{l}\text { Descriptive, } \\
\text { comparative } \\
\text { design with } \\
592 \\
\text { clinicians } \\
\text { via surveys. } \\
\text { Level I } \\
\text { QR = A }\end{array}$ & $\begin{array}{l}\text { Data from } \\
592 \text { clinicians } \\
\text { in } 825 \text { bed } \\
\text { level I trauma } \\
\text { medical } \\
\text { center in VA. }\end{array}$ & $\begin{array}{l}\text { Instruments: } \\
\text { 1) Demographic } \\
\text { information. } \\
\text { 2)Moral } \\
\text { Distress Sale } \\
\text { Revised (MDS- } \\
\text { R). } \\
\text { 3)Olson's } \\
\text { Hospital Ethical } \\
\text { Climate Scale } \\
\text { (HECS-S). }\end{array}$ & $\begin{array}{l}\text { To assess moral } \\
\text { distress and } \\
\text { compare } \\
\text { differences } \\
\text { among } \\
\text { professions and } \\
\text { settings. }\end{array}$ & $\begin{array}{l}\text { Moral distress } \\
\text { is a common } \\
\text { experience for } \\
\text { clinicians } \\
\text { regardless of } \\
\text { professions. }\end{array}$ & $\begin{array}{l}\text { 1) Lack of continuity and poor team } \\
\text { communication are most common } \\
\text { sources of moral distress. } \\
\text { 2) Strategies to enhance } \\
\text { communication and teamwork. } \\
\text { 3) Moral distress experienced by all } \\
\text { clinician in this study. } \\
\text { 4) End of life issues trigger moral } \\
\text { distress. }\end{array}$ \\
\hline
\end{tabular}




\begin{tabular}{|c|c|c|c|c|c|c|}
\hline $\begin{array}{l}\text { Ko, H.-K., Chin, C.-C., \& } \\
\text { Hsu, M-T. (2018). Moral } \\
\text { distress model } \\
\text { reconstructed using } \\
\text { grounded theory. The } \\
\text { Journal of Nursing } \\
\text { Research, } 26(1), 18-26 .\end{array}$ & $\begin{array}{l}\text { Data via } \\
\text { interviews } \\
\text { with } 25 \text { staff } \\
\text { nurses. } \\
\text { Level II } \\
\text { QR = B }\end{array}$ & $\begin{array}{l}\text { Participants } \\
\text { were } 25 \text { staff } \\
\text { nurses } \\
\text { recruited from } \\
\text { three teaching } \\
\text { hospitals in } \\
\text { Taiwan. }\end{array}$ & $\begin{array}{l}\text { Data collected } \\
\text { using 2-3-hour } \\
\text { interviews and } \\
\text { audio recorded. }\end{array}$ & $\begin{array}{l}\text { To reconstruct the } \\
\text { model of moral } \\
\text { distress using the } \\
\text { grounded theory. }\end{array}$ & $\begin{array}{l}\text { Moral distress } \\
\text { affects the job } \\
\text { satisfaction, } \\
\text { retention, and } \\
\text { burnout of } \\
\text { nurses as well } \\
\text { as patient } \\
\text { safety and } \\
\text { quality of } \\
\text { nursing care. }\end{array}$ & $\begin{array}{l}\text { 1)Moral values shared with our } \\
\text { countries are patient safety, patients' } \\
\text { rights and accountability. } \\
\text { 2)The risk of emotional reactions } \\
\text { rises significantly when a nurse } \\
\text { doubts his or her ability to do the } \\
\text { right thing or cannot ensure the } \\
\text { patient's best interest. } \\
\text { 3) Nonexplicit emotions of } \\
\text { frustration, helplessness and anger } \\
\text { exist in moral distress. } \\
\text { 4) Self-doubt is an internal } \\
\text { constraint. } \\
\text { 5) Core values, knowledge, attitude } \\
\text { and communication skills learned } \\
\text { from nursing education may become } \\
\text { guides for the working nurse. }\end{array}$ \\
\hline $\begin{array}{l}\text { Genly, B. (2016). Safety \& } \\
\text { job burnout. } \\
\text { Understanding complex } \\
\text { contributing factors. } \\
\text { Professional Safety, } \\
\text { 61(10), 45-49. }\end{array}$ & $\begin{array}{l}\text { Research } \\
\text { based } \\
\text { authority/ex } \\
\text { pert. } \\
\text { Level III } \\
\text { QR= A }\end{array}$ & $\begin{array}{l}\text { Multi- } \\
\text { industry } \\
\text { review of } \\
\text { studies on } \\
\text { burnout. }\end{array}$ & $\begin{array}{l}\text { Maslach } \\
\text { Burnout } \\
\text { Inventory } \\
\text { (MBI): } \\
\text { 1) Emotional } \\
\text { exhaustion } \\
\text { 2) } \\
\text { Depersonalizati } \\
\text { on } \\
\text { 3) Inefficacy } \\
\end{array}$ & $\begin{array}{l}\text { Defines burnout, } \\
\text { connections } \\
\text { between } \\
\text { workplace safety. }\end{array}$ & $\begin{array}{l}\text { Outlines } \\
\text { interventions to } \\
\text { prevent } \\
\text { burnout and } \\
\text { increase } \\
\text { workplace } \\
\text { safety. }\end{array}$ & $\begin{array}{l}\text { 1) Burnout leads to absenteeism and } \\
\text { turnover. } \\
\text { 2) Improvement in staffing levels } \\
\text { reduced nurse burnout by reducing } \\
\text { nurses' patient workload. } \\
\text { Safety-oriented burnout } \\
\text { interventions include self-care, } \\
\text { reflections and recognition, } \\
\text { community, coping styles and } \\
\text { structure. }\end{array}$ \\
\hline $\begin{array}{l}\text { Minamizono, s., Nomura, } \\
\text { K., Inoue, Hiraike, H., } \\
\text { Tsuchiya, A., \& Illing, J. } \\
\text { (2019). Gender division of } \\
\text { labor, burnout and } \\
\text { intention to leave work } \\
\text { among young female nurse } \\
\text { in Japan: A cross-sectional } \\
\text { study. International } \\
\text { Journal of Environmental } \\
\text { Research and Public } \\
\text { Health, 16(12), 12p. }\end{array}$ & $\begin{array}{l}\text { Cross- } \\
\text { sectional } \\
\text { study using } \\
\text { secondary } \\
\text { data from a } \\
\text { survey of } \\
\text { work-family } \\
\text { conflict. } \\
\text { Level II } \\
\text { QR - A }\end{array}$ & $\begin{array}{l}\text { For this study } \\
328 \text { nurses } \\
\text { were analyzed } \\
\text { from a large } \\
\text { private } \\
\text { medical } \\
\text { university. }\end{array}$ & $\begin{array}{l}\text { Questionnaires } \\
\text { addressing } \\
\text { personal factors, } \\
\text { work } \\
\text { environment, } \\
\text { individual } \\
\text { perceptions, } \\
\text { intention to } \\
\text { leave. } \\
\text { Job Contents } \\
\text { Questionnaire } \\
\text { (JCQ). }\end{array}$ & $\begin{array}{l}\text { Investigate if } \\
\text { gender division of } \\
\text { labor affects the } \\
\text { intention to leave. }\end{array}$ & $\begin{array}{l}\text { Gender } \\
\text { division of } \\
\text { labor is not a } \\
\text { determinant of } \\
\text { intention to } \\
\text { leave. }\end{array}$ & $\begin{array}{l}\text { Those who scored high on burnout } \\
\text { are vulnerable population. }\end{array}$ \\
\hline
\end{tabular}




\begin{tabular}{|c|c|c|c|c|c|c|}
\hline & & & $\begin{array}{l}\text { Copenhagen } \\
\text { burnout } \\
\text { inventory form. }\end{array}$ & & & \\
\hline $\begin{array}{l}\text { Ke, Y-T., \& Hung, C-H. } \\
\text { (2017). Predictors of } \\
\text { nurses' intent to continue } \\
\text { working at their current } \\
\text { hospital. Nursing } \\
\text { Economics, 35(50, 259- } \\
266 .\end{array}$ & $\begin{array}{l}\text { Cross- } \\
\text { sectional } \\
\text { study design } \\
\text { with } \\
\text { structured } \\
\text { questionnair } \\
\text { es. } \\
\text { Level I } \\
\text { QR = A }\end{array}$ & $\begin{array}{l}\text { Site A: } 1,200 \\
\text { nurses and } \\
\text { Site B: } 1,175 \\
\text { nurses. Site C: } \\
687 \text { nurses. } \\
\text { Site d: } 361 \\
\text { nurses. Total } \\
\text { of } 3,423 \\
\text { nurses. } \\
\text { Inclusion } \\
\text { were } \\
\text { registered } \\
\text { nurses, } \\
\text { working at } \\
\text { medical } \\
\text { center or } \\
\text { regional } \\
\text { teaching } \\
\text { hospital with } \\
\text { one or more } \\
\text { years in } \\
\text { nursing. }\end{array}$ & $\begin{array}{l}\text { Structured } \\
\text { questionnaires } \\
\text { and } \\
\text { demographics. } \\
\text { 1) Nurses Intent } \\
\text { to Stay Scale. } \\
\text { Validity - 1.00, } \\
\text { Cronbach's } \\
\text { alpha } 0.75 . \\
\text { 2) } \\
\text { Organizational } \\
\text { Climate Scale. } \\
\text { Validity = 0.95. } \\
\text { Cronbach's } \\
\text { alpha } 0.84 .\end{array}$ & $\begin{array}{l}\text { To identify } \\
\text { predictors of } \\
\text { nurses' intent to } \\
\text { stay at their } \\
\text { current jobs. }\end{array}$ & $\begin{array}{l}\text { Intention to } \\
\text { stay related to } \\
\text { age, marital } \\
\text { status, working } \\
\text { years, clinical } \\
\text { ladder, working } \\
\text { unit, choice of } \\
\text { working in } \\
\text { current hospital } \\
\text { and } \\
\text { organizational } \\
\text { climate. }\end{array}$ & $\begin{array}{l}\text { 1) Positive organizational climate, } \\
\text { personal choice of working at their } \\
\text { hospital and age were positive } \\
\text { predictors. } \\
\text { 2) Working in ICU was a negative } \\
\text { predictor of nurses' intent to stay. } \\
\text { 3) Supportive organizational } \\
\text { climates increase nurses' intent to } \\
\text { stay. }\end{array}$ \\
\hline $\begin{array}{l}\text { Hussein, R., Salamonson, } \\
\text { Y., Hu, W., \& Everett, B. } \\
\text { (2019). Clinical } \\
\text { supervision and ward } \\
\text { orientation predict new } \\
\text { graduate nurses' intention } \\
\text { to work in critical care: } \\
\text { Findings from a } \\
\text { prospective observational } \\
\text { study. Australian Critical } \\
\text { Care, 32, 397-402. }\end{array}$ & $\begin{array}{l}\text { New } \\
\text { graduate } \\
\text { nurses } \\
\text { surveyed at } \\
\text { the end of } \\
\text { their } \\
\text { transitional } \\
\text { program. } \\
\text { Level II } \\
\text { QR = A }\end{array}$ & $\begin{array}{l}\text { Total of } 109 \\
\text { new graduate } \\
\text { nurses } \\
\text { consented to } \\
\text { participate. } \\
\text { Follow up } \\
\text { with } 87 \text { who } \\
\text { completed } \\
\text { surveys. } \\
\text { Study setting } \\
\text { was general } \\
\text { intensive care. }\end{array}$ & $\begin{array}{l}\text { 1) Manchester } \\
\text { Clinical } \\
\text { Supervision } \\
\text { Scale (MCSS- } \\
\text { 26). Cronbach' } \\
\text { alpha 0.66-0.87. } \\
\text { 2)Practice } \\
\text { Environment } \\
\text { Scale, Australia } \\
\text { (PES-AUS). } \\
\text { 3)Intention to } \\
\text { Stay in Clinical } \\
\text { Specialty } \\
\text { adapted from } \\
\text { Nurse Retention }\end{array}$ & $\begin{array}{l}\text { To examine new } \\
\text { graduate nurses' } \\
\text { perceptions and } \\
\text { how they } \\
\text { influenced their } \\
\text { intention to stay } \\
\text { following their } \\
\text { transitional } \\
\text { program. }\end{array}$ & $\begin{array}{l}\text { New graduates } \\
\text { in critical care } \\
\text { were six times } \\
\text { more likely to } \\
\text { indicate } \\
\text { intention to } \\
\text { stay than on } \\
\text { other units. }\end{array}$ & $\begin{array}{l}\text { 1) Intention to leave nursing is } \\
\text { reportedly more common among } \\
\text { young and newly graduated nurses. } \\
\text { 2) Age I not a predictor of intention } \\
\text { to stay. } \\
\text { 3) New graduate nurses felt more } \\
\text { supported in ICUs. } \\
\text { 4) New graduates more likely to } \\
\text { stay when not placed in situation } \\
\text { where they have to work beyond } \\
\text { their clinical capability. } \\
\text { 5) A good orientation and clinical } \\
\text { supervision increase intention to } \\
\text { stay in ICU. }\end{array}$ \\
\hline
\end{tabular}




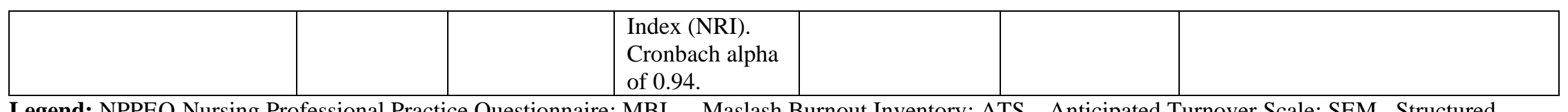

Legend: NPPEQ Nursing Professional Practice Questionnaire; MBI Maslash Burnout Inventory; ATS Anticipated Turnover Scale; SEM Structured Equation Modelling

ICU Intensive Care Unit; NPE Nurse Practice Environment; PROQOL5 Professional Quality of Life Scale version 5; STS Secondary Traumatic Stress; EDMCQ Ethical Decision-Making Climate Questionnaire; PES-NWD Practice Environment Scale of Nursing Work Index; CFS Change Fatigue Scale ;

CDRS Connor-Davidson Resilience Scale ; MMSS McCloskey/Mueller Satisfaction Scale ; ToxBH-NM Toxic Leadership Behaviors of Nurse Manager; JSS Job Satisfaction Scale; GTL Global Transformation Leadership Scale; PSS Perceived Stress Scale; MDS-R Moral Distress Scale Revised; HECS-S Olson's Hospital Ethical Climate Scale

JCQ Job Contents Questionnaire ; MCSS-26 Manchester Clinical Supervision Scale ; PES-AUS Practice Environment Scale, Australia ; NRI Nurse Retention Index 
Appendix B

\begin{tabular}{|c|c|c|c|c|c|c|c|}
\hline \begin{tabular}{|l|} 
Summary of \\
Systematic \\
Reviews (SR) \\
Citation
\end{tabular} & $\begin{array}{l}\text { Quality } \\
\text { Grade }\end{array}$ & Question & $\begin{array}{l}\text { Search } \\
\text { Strategy }\end{array}$ & $\begin{array}{l}\text { Inclusion/ } \\
\text { Exclusion Criteria }\end{array}$ & $\begin{array}{l}\text { Data Extraction } \\
\text { and Analysis }\end{array}$ & Key Findings & $\begin{array}{l}\text { Usefulness/Recommend } \\
\text { ation/ } \\
\text { Implications }\end{array}$ \\
\hline $\begin{array}{l}\text { Putra, A.P., } \\
\text { Kusnanto,K., } \\
\text { Yuwono, S.R. } \\
\text { (2020). Effect of } \\
\text { job satisfaction } \\
\text { and organizational } \\
\text { commitment on } \\
\text { nurse retention: A } \\
\text { systematic review. } \\
\text { Indonesian } \\
\text { Nursing Journal } \\
\text { of Education and } \\
\text { Clinic, 5(2), 197- } \\
205 .\end{array}$ & $\begin{array}{l}\text { Level II } \\
\mathrm{QR}=\mathrm{A}\end{array}$ & $\begin{array}{l}\text { What is the } \\
\text { effect of job } \\
\text { satisfaction } \\
\text { and } \\
\text { organizationa } \\
1 \\
\text { commitment } \\
\text { on nurse } \\
\text { retention? }\end{array}$ & $\begin{array}{l}\text { Nurse } \\
\text { retention, } \\
\text { Job } \\
\text { satisfaction. }\end{array}$ & $\begin{array}{l}\text { Nurse retention, nurse } \\
\text { retention strategies. }\end{array}$ & $\begin{array}{l}\text { Job satisfaction and } \\
\text { organizational } \\
\text { commitment can be } \\
\text { influenced by age, } \\
\text { marriage education } \\
\text { level and length of } \\
\text { work. }\end{array}$ & $\begin{array}{l}\text { 1) Job satisfaction can } \\
\text { motivate performance } \\
\text { reducing absenteeism } \\
\text { and turnover rates. } \\
\text { 2) Job satisfaction is } \\
\text { most widely explained } \\
\text { cause of nurse } \\
\text { turnover in the } \\
\text { literature. } \\
\text { 3)Organizational } \\
\text { commitment } \\
\text { influences nurse } \\
\text { retention and is a } \\
\text { predictor for nurse } \\
\text { turnover. } \\
\end{array}$ & $\begin{array}{l}\text { 1) Job satisfaction and } \\
\text { organizational } \\
\text { commitment have an } \\
\text { influence on nurse } \\
\text { retention. } \\
\text { 2)Effective nurse } \\
\text { retention strategies may } \\
\text { be created to increase } \\
\text { nurse retention. }\end{array}$ \\
\hline $\begin{array}{l}\text { Brook, J., Aitken, } \\
\text { L., Webb, R., } \\
\text { MacLaren, J., \& } \\
\text { Salmon. (2019). } \\
\text { Characteristics of } \\
\text { successful } \\
\text { interventions to } \\
\text { reduce turnover } \\
\text { and increase } \\
\text { retention of early } \\
\text { career nurses: A } \\
\text { systematic review. } \\
\text { International } \\
\text { Journal of } \\
\text { Nursing Studies, } \\
\text { 91, 47-59. }\end{array}$ & $\begin{array}{l}\text { Level II } \\
\mathrm{QR}=\mathrm{A}\end{array}$ & $\begin{array}{l}\text { What are } \\
\text { successful } \\
\text { intervention } \\
\text { to reduce } \\
\text { turnover and } \\
\text { increase } \\
\text { retention of } \\
\text { early career } \\
\text { nurses? }\end{array}$ & \begin{tabular}{|l|} 
Retain, \\
retention, \\
attrition, leave, \\
turnover, quit, \\
loyalty AND \\
staff, \\
personnel, \\
employee, \\
workforce, \\
nurse.
\end{tabular} & $\begin{array}{l}\text { Nurse turnover, nurse } \\
\text { retention. }\end{array}$ & $\begin{array}{l}\text { Highest benefit is } \\
\text { internship/residenc } \\
\text { y program \& } \\
\text { mentorship. }\end{array}$ & $\begin{array}{l}\text { Programs with } \\
\text { teaching, preceptor } \\
\text { and mentor } \\
\text { component are best. } \\
\text { Orientation and } \\
\text { transition to practice } \\
\text { programs should } \\
\text { involve formal } \\
\text { teaching and a } \\
\text { mentor/preceptor. } \\
\text { Clinical Ladder or } \\
\text { Advancement } \\
\text { programs involve }\end{array}$ & $\begin{array}{l}\text { 1) Effective interventions } \\
\text { are mentorship and } \\
\text { preceptorship. } \\
\text { 2) Teaching/training } \\
\text { important. } \\
\text { 3)Strategies } \\
\text { incorporating several } \\
\text { methods of education } \\
\text { with strong preceptor } \\
\text { optimal. }\end{array}$ \\
\hline
\end{tabular}




\begin{tabular}{|l|l|l|l|l|l|l|l|}
\hline $\begin{array}{l}\text { Summary of } \\
\text { Systematic } \\
\text { Reviews (SR) } \\
\text { Citation }\end{array}$ & $\begin{array}{l}\text { Guality } \\
\text { Grade }\end{array}$ & Question & $\begin{array}{l}\text { Search } \\
\text { Strategy }\end{array}$ & $\begin{array}{l}\text { Inclusion/ } \\
\text { Exclusion Criteria }\end{array}$ & $\begin{array}{l}\text { Data Extraction } \\
\text { and Analysis }\end{array}$ & Key Findings & $\begin{array}{l}\text { Usefulness/Recommend } \\
\text { ation/ } \\
\text { Implications }\end{array}$ \\
\hline & & & & & & & \\
\hline
\end{tabular}

Legend: 


\section{Appendix C}

\section{Project Schedule}

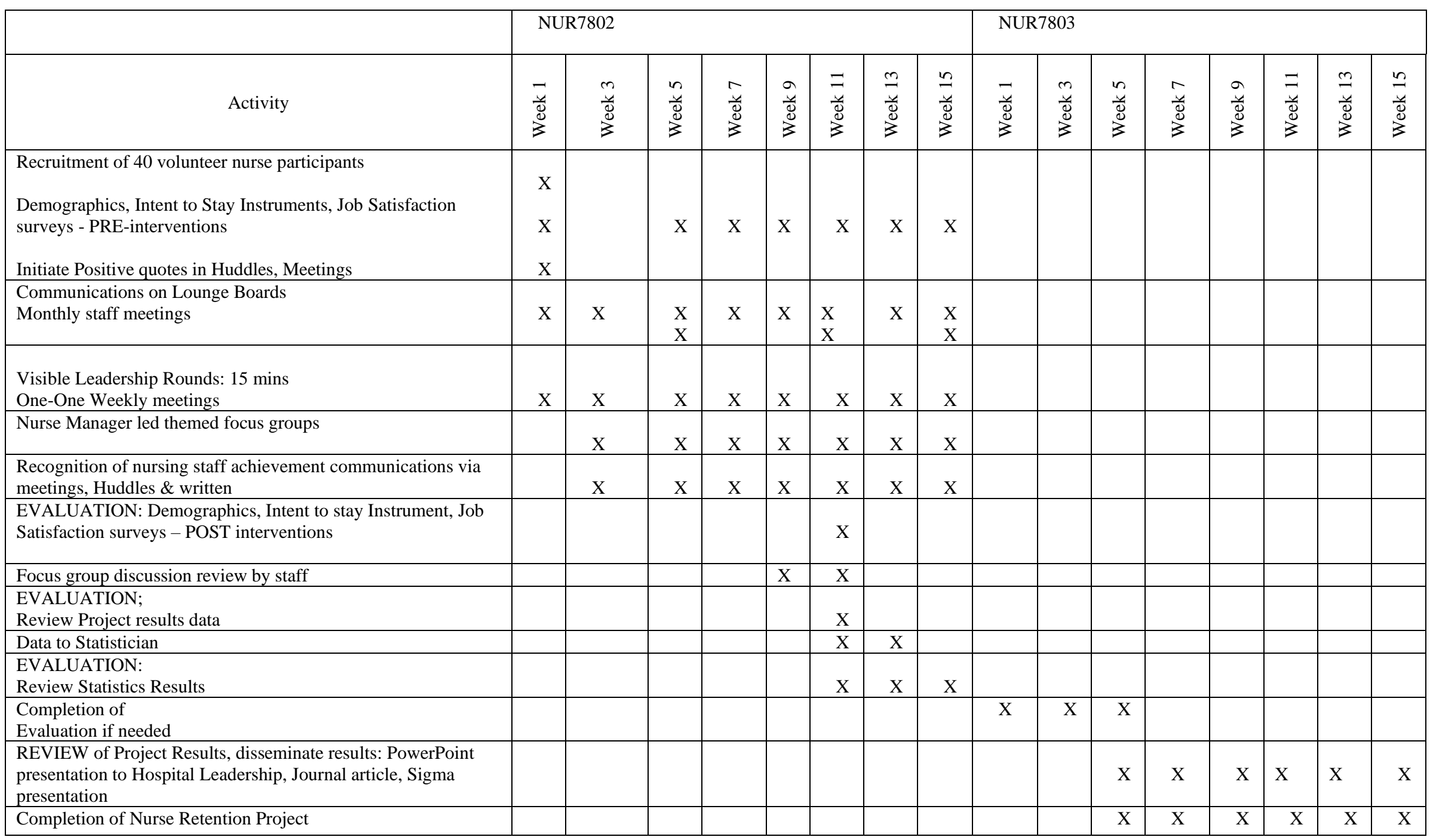




\section{Appendix D}

\section{Job Satisfaction Survey}

\begin{tabular}{|c|c|c|c|c|c|c|c|}
\hline & $\begin{array}{c}\text { JOB SATISFACTION SURVEY } \\
\text { Paul E. Spector } \\
\text { Department of Psychology } \\
\text { University of South Florida } \\
\text { Copyright Paul E. Spector 1994, All rights reserved. }\end{array}$ & & & & & & \\
\hline & $\begin{array}{l}\text { PLEASE CIRCLE THE ONE NUMBER FOR EACH QUESTION } \\
\text { THAT COMES CLOSEST TO REFLECTING YOUR OPINION } \\
\text { ABOUT IT. }\end{array}$ & 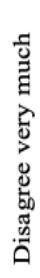 & 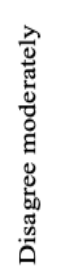 & 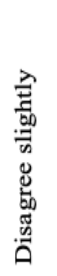 & 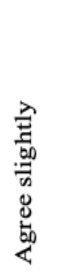 & $\begin{array}{l}\frac{\lambda}{0} \\
\frac{\pi}{0} \\
\frac{0}{0} \\
0 \\
0 \\
0 \\
0 \\
\frac{0}{4}\end{array}$ & 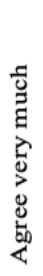 \\
\hline 1 & I feel I am being paid a fair amount for the work I do. & 1 & 2 & 3 & 4 & 5 & 6 \\
\hline 2 & There is really too little chance for promotion on my job. & 1 & 2 & 3 & 4 & 5 & 6 \\
\hline 3 & My supervisor is quite competent in doing his/her job. & 1 & 2 & 3 & 4 & 5 & 6 \\
\hline 4 & I am not satisfied with the benefits I receive. & 1 & 2 & 3 & 4 & 5 & 6 \\
\hline 5 & When I do a good job, I receive the recognition for it that I should receive. & & 2 & 3 & 4 & 5 & 6 \\
\hline 6 & Many of our rules and procedures make doing a good job difficult. & & 2 & 3 & 4 & 5 & 6 \\
\hline 7 & I like the people I work with. & & 2 & 3 & 4 & 5 & 6 \\
\hline 8 & I sometimes feel my job is meaningless. & 1 & 2 & 3 & 4 & 5 & 6 \\
\hline 9 & Communications seem good within this organization. & 1 & 2 & 3 & 4 & 5 & 6 \\
\hline 10 & Raises are too few and far between. & & 2 & 3 & 4 & 5 & 6 \\
\hline 11 & Those who do well on the job stand a fair chance of being promoted. & & 2 & 3 & 4 & 5 & 6 \\
\hline 12 & My supervisor is unfair to me. & 1 & 2 & 3 & 4 & 5 & 6 \\
\hline 13 & The benefits we receive are as good as most other organizations offer. & & 2 & 3 & 4 & 5 & 6 \\
\hline 14 & I do not feel that the work I do is appreciated. & & 2 & 3 & 4 & 5 & 6 \\
\hline 15 & My efforts to do a good job are seldom blocked by red tape. & & 2 & 3 & 4 & 5 & 6 \\
\hline 16 & $\begin{array}{l}\text { I find I have to work harder at my job because of the incompetence of } \\
\text { people I work with. }\end{array}$ & & 2 & 3 & 4 & 5 & 6 \\
\hline 17 & I like doing the things I do at work. & 1 & 2 & 3 & 4 & 5 & 6 \\
\hline 18 & The goals of this organization are not clear to me. & 1 & 2 & 3 & 4 & 5 & 6 \\
\hline
\end{tabular}




\begin{tabular}{|c|c|c|c|c|c|c|c|}
\hline & $\begin{array}{c}\text { PLEASE CIRCLE THE ONE NUMBER FOR EACH QUESTION } \\
\text { THAT COMES CLOSEST TO REFLECTING YOUR OPINION } \\
\text { ABOUT IT. } \\
\text { Copyright Paul E. Spector 1994, All rights reserved. }\end{array}$ & 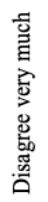 & 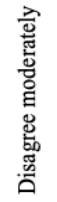 & 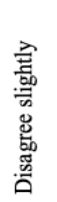 & 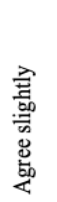 & 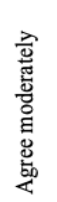 & 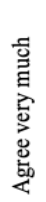 \\
\hline 19 & $\begin{array}{l}\text { I feel unappreciated by the organization when I think about what they pay } \\
\text { me. }\end{array}$ & 1 & 2 & 3 & 4 & 5 & 6 \\
\hline 20 & People get ahead as fast here as they do in other places. & 1 & 2 & 3 & 4 & 5 & 6 \\
\hline 21 & My supervisor shows too little interest in the feelings of subordinates. & 1 & 2 & 3 & 4 & 5 & 6 \\
\hline 22 & The benefit package we have is equitable. & 1 & 2 & 3 & 4 & 5 & 6 \\
\hline 23 & There are few rewards for those who work here. & 1 & 2 & 3 & 4 & 5 & 6 \\
\hline 24 & I have too much to do at work. & 1 & 2 & 3 & 4 & 5 & 6 \\
\hline 25 & I enjoy my coworkers. & 1 & 2 & 3 & 4 & 5 & 6 \\
\hline 26 & I often feel that I do not know what is going on with the organization. & 1 & 2 & 3 & 4 & 5 & 6 \\
\hline 27 & I feel a sense of pride in doing my job. & 1 & 2 & 3 & 4 & 5 & 6 \\
\hline 28 & I feel satisfied with my chances for salary increases. & 1 & 2 & 3 & 4 & 5 & 6 \\
\hline 29 & There are benefits we do not have which we should have. & 1 & 2 & 3 & 4 & 5 & 6 \\
\hline 30 & I like my supervisor. & 1 & 2 & 3 & 4 & 5 & 6 \\
\hline 31 & I have too much paperwork. & 1 & 2 & 3 & 4 & 5 & 6 \\
\hline 32 & I don't feel my efforts are rewarded the way they should be. & 1 & 2 & 3 & 4 & 5 & 6 \\
\hline 33 & I am satisfied with my chances for promotion. & 1 & 2 & 3 & 4 & 5 & 6 \\
\hline 34 & There is too much bickering and fighting at work. & 1 & 2 & 3 & 4 & 5 & 6 \\
\hline 35 & My job is enjoyable. & 1 & 2 & 3 & 4 & 5 & 6 \\
\hline 36 & Work assignments are not fully explained. & 1 & 2 & 3 & 4 & 5 & 6 \\
\hline
\end{tabular}

\section{Job Satisfaction Survey Permission - Conditions for Using These Assessments}

* All of the assessments in the Our Assessments section of paulspector.com are copyrighted.

* You have my permission for free noncommercial research/teaching use of any of the assessments that are in the Our Assessments section of paulspector.com. This includes student theses and dissertations, as well as other student research projects. Copies of the scale can be reproduced in a thesis or dissertation as long as the copyright notice is included, as shown in the downloadable copy of each scale.

* For commercial uses there is a fee for using these scales. A commercial use means you are charging someone a fee to provide a service that includes use of one or more of these scales. Contact me at paul@paulspector.com to discuss fees for commercial use. 


\section{Appendix E}

\section{McCain's Behavioral Commitment Scale}

McCain's Intent to Stay Scale

(A 5-Item Subscale from McCain's Behavioral Commitment Scale)

Purpose: To assess the staff nurse's perception of the likelihood to stay in her or his current job.

Instructions: For each nurse receiving the nurse retention guideline, please have the nurse complete the McCain's Intent to Stay Scale. This scale should be completed at baseline (before guideline is initiated) and on a 6-month basis.

Scoring: Each item is scored from 1 "strongly disagree" to 5 "strongly agree". Scores are summed and divided by the number of items to attain a mean. A higher score indicated higher intent to stay.

Directions: Please circle the number that best reflects your response to each statement.

\begin{tabular}{|l|c|c|c|c|c|}
\hline \multicolumn{1}{|c|}{ ITEMS } & $\begin{array}{c}\text { Strongly } \\
\text { Agree }\end{array}$ & Agree & Neutral & Disagree & $\begin{array}{c}\text { Strongly } \\
\text { Disagree }\end{array}$ \\
\hline \begin{tabular}{l} 
1. $\quad \begin{array}{l}\text { I plan to work at my present job } \\
\text { for as long as possible. }\end{array}$ \\
\hline $\begin{array}{l}\text { 2. } \quad \text { I will probably spend the rest of } \\
\text { my career in this job or the jobs } \\
\text { that it leads to in this hospital. }\end{array}$
\end{tabular} & 5 & 4 & 3 & 2 & 1 \\
\hline 3. $\quad \begin{array}{l}\text { Even if this job does not meet all } \\
\text { my expectations, I will not quit. }\end{array}$ & 5 & 4 & 3 & 2 & 1 \\
\hline $4 . \quad \begin{array}{l}\text { Under no circumstances would I } \\
\text { leave my present job. }\end{array}$ & 5 & 4 & 3 & 2 & 1 \\
\hline 5. $\quad \begin{array}{l}\text { I plan to keep this job for at least } \\
\text { two or three years. }\end{array}$ & 5 & 4 & 3 & 2 & 1 \\
\hline
\end{tabular}

\section{References:}

McCloskey, J. C. (1990). Two requirements for job contentment: Autonomy and social integration. Image: Journal of Nursing Scholarship, 22(3), 140-143.

Tang, J. H-C. (2005). Hospital nurses' perceptions of family responsive workplace policies: Relationship to job satisfaction and intent to stay [unpublished dissertation]. University of Iowa, Iowa City, IA.

This tool is in the public domain. 


\section{Appendix F}

\section{Permission is within the public domain}

Demographic Data

Participant \# Date Dept

To assist in data analysis and interpretation, please provide the following information. All information will be held strictly confidential.

Circle the number beside your age range (1) 2-30 (2) 31-40 (3) 41-50 (4) 51-64 (5) $65+$

What is your ethnicity?

(1) African American (2) American Indian or Alaskan Native (3) Asian (4) Caucasian

(5) Hispanic/Latino (6) Native Hawaiian or other Pacific Islander (7) Other

To which identity do you most identify?

(1) Female (2) Male (3) Transgender Female. (4) Transgender Male (5) Gender Variant/NonConforming (6) Not Listed (7) Prefer not to answer

Circle the number beside your highest level of nursing education

(1) LVN (2) ADN (3) Diploma (4) BSN (5) Master's Degree in Nursing (6) Doctorate

(7) Other

Circle the number of years of nursing experience you have (1) $6 \mathrm{mo}-1 \mathrm{yr}$ (2) 1 - 3 yrs (3) 4-5 yrs (4) 6-10 yrs (5) $11+$ yrs

What level of expertise do you believe that you have?

(1) novice (2) advanced beginner (3) competent (4) proficient (5) expert

What is your relationship status?

(1) Single (2) Married (3) Widowed. (4) Divorced (5) Divorced. (6) Other 


\section{Appendix G}

\section{SWOT Analysis}

\begin{tabular}{|c|c|c|c|}
\hline Strength & Weakness & Opportunity & Threat \\
\hline $\begin{array}{l}\text { Busy Critical Care } \\
\text { Units }\end{array}$ & Nursing Shortage & $\begin{array}{l}\text { The hospital is a } \\
\text { Main Stay in } \\
\text { The Community }\end{array}$ & $\begin{array}{c}\text { Negative Media } \\
\text { Coverage }\end{array}$ \\
\hline $\begin{array}{l}\text { Stable Expert } \\
\text { Nursing Staff }\end{array}$ & $\begin{array}{l}\text { Large Nursing } \\
\text { Turnover }\end{array}$ & $\begin{array}{l}\text { Largest Employer } \\
\text { in the Area }\end{array}$ & $\begin{array}{l}\text { Nursing Jobs offers } \\
\text { from other } \\
\text { Organizations }\end{array}$ \\
\hline Adequate Resources & $\begin{array}{c}\text { Poor } \\
\text { Nurse Retention }\end{array}$ & $\begin{array}{l}\text { New Graduate } \\
\text { Nursing Program }\end{array}$ & $\begin{array}{l}\text { Perception of } \\
\text { Unsupportive } \\
\text { Management }\end{array}$ \\
\hline $\begin{array}{l}\text { Known for the } \\
\text { New Graduate } \\
\text { Nursing Program }\end{array}$ & Inadequate Staffing & & \\
\hline
\end{tabular}




\section{Appendix H}

Johns Hopkins Evidence Tables

Authors

Rivaz et al. (2020)

Jakimowicz et al. (2018)

Van den Bulcke, et al. (2020)

Moisoglou et al. (2020)

Lee et al. (2019)

Dewanto \& Warhani (2018)

Coundounaris et al. (2020)

Brown et al. (2018)

Semachew et al. (2017)

Labrague et al. (2020)

Nurdiana et al. (2018)

Adams et al. (2019)

Tang \& Hudson (2019)

Whitehead et al. (2015)

Ko et al. (2018)

Genly (206)

Minamizono et al. (2019)

Ke et al. (2017)

Hussein et al. (2019)

Putra et al. (2020)

Brook et al. (2019)
Level

Quality Rating

I

II

I

I

I

I

II

I

II

I

I

II

IV

I

II

III

II

I

II

II

II

A

B

A

A

A

A

B

A

A

A

A

B

A

A

B

A

A

A

A

A

A 


\section{Appendix I}

\section{Johns Hopkins Nursing Practice Evidence-Based Practice}

\section{Evidence Level and Quality Guide}

Evidence Levels

\section{Level I}

Randomized controlled studies (RCT)

Explanatory mixed method design

Systematic reviews of RCTs

\section{Level II}

Quasi-experimental study

Explanatory mixed method design

Systematic review of a combination

Of RCTs and quasi-experimental studies

Or quasi-experimental studies only

\section{Level III}

Nonexperimental study

Systematic review of a combination of

RCTs, quasi-experimental and non-

Experimental studies only

\section{Level IV}

Opinion of respected authorities

Clinical practice guidelines

Consensus of panels/position statements
Quality Ratings

\section{Quantitative Studies}

A - High Quality: Consistent, generalized results

B - Good quality: Reasonably consistent results

C- Low quality or major flaws: Little evidence with inconsistent results
Qualitative Studies

A/B - High/Good quality: single studies

C - Low quality: studies contribute little to overall review of findings
A - High quality: Materials sponsored by professional, public, private organization or government agency, consistent results

B - Good quality: Organization or government agency materials, reasonably consistent results

C - Low quality or major flaws: Insufficient evidence with inconsistent results, not governmental or organizationally sponsored material.

\section{Level V}

Integrative reviews

Literature reviews

Quality improvement

\section{A- High quality: expertise clearly}

is clearly evident, definitive conclusions

B - Good quality: Expertise appears credible, fairly definitive conclusions

C - Low quality or major flaws:

Expertise is not discernible, Conclusions cannot be drawn

Adapted from Johns Hopkin Hospital/Johns Hopkins University School of Nursing 2017 